\title{
Reconnecting European Political Parties with European Union Citizens
}

International IDEA Discussion Paper 6/2018 


\section{Reconnecting European Political Parties with European Union Citizens}

International IDEA Discussion Paper 6/2018

Lead author: Steven van Hecke

Contributors: Alex Andrione-Moylan, Nathalie Brack, Isabelle de Coninck, Stephen Day, Wojciech Gagatek, Emilie van Haute, Isabelle Hertner, Karl

Magnus Johansson, Teona Lavrelashvili, Gilles Pittoors and Wouter Wolfs 
(C) 2018 International Institute for Democracy and Electoral Assistance

International IDEA publications are independent of specific national or political interests. Views expressed in this publication do not necessarily represent the views of International IDEA, its Board or its Council members.

\section{(c) (i) (2)(2)}

The electronic version of this publication is available under a Creative Commons Attribute-NonCommercial-ShareAlike 3.0 (CC BY-NC-SA 3.0) licence. You are free to copy, distribute and transmit the publication as well as to remix and adapt it, provided it is only for non-commercial purposes, that you appropriately attribute the publication, and that you distribute it under an identical licence. For more information on this licence visit the Creative Commons website: 〈http://creativecommons.org/licenses/by-nc-sa/3.0/〉.

International IDEA

Strömsborg

SE-103 34 Stockholm

Sweden

Telephone: +4686983700

Email: info@idea.int

Website: 〈http://www.idea.int〉

Design and layout: International IDEA

DOI: 〈https://doi.org/10.31752/idea.2018.71〉

Created with Booktype: 〈https://www.booktype.pro〉 


\section{Contents}

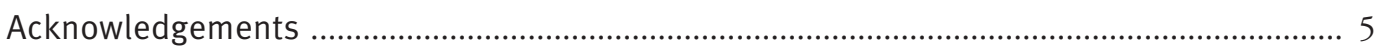

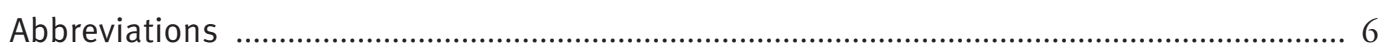

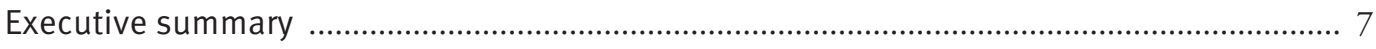

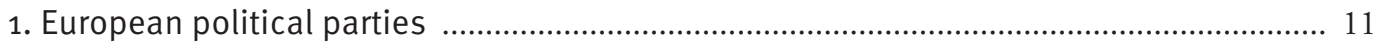

2. Improving European political parties' connection with citizens through regulation ....... 23

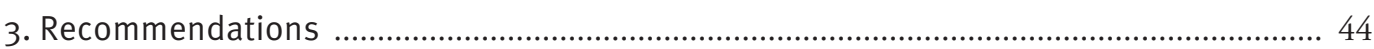

Annex. Proposals on transnational lists for the European Parliament …............................. 50

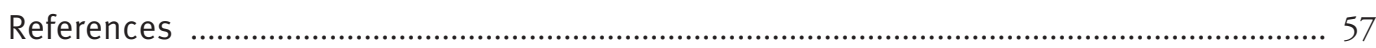

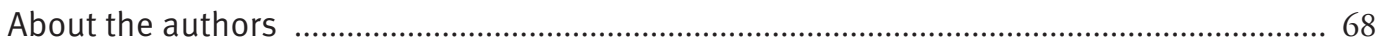

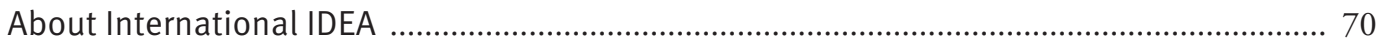




\section{Acknowledgements}

This paper was commissioned by the Office of International IDEA to the European Union. It was compiled by Steven van Hecke and a team of contributors, including senior and junior academics from various universities, who shared their expertise and insights on different aspects of the role European political parties play within the European Union polity, based on the state of play in December 2017. The sections to which they contributed inform the recommendations at the end of the paper.

Special thanks to the representatives of European political parties and other participants in the expert round table and public panel debate, organized by the Office of International IDEA to the European Union, which took place in Brussels on 13 July and 23 November 2017, respectively. Additional information about the round table is available on International IDEA's website (Neven 2017).

Finally, thanks to Andrew Bradley, Director, and Marilyn Neven, Programme Manager, of the Office of International IDEA to the European Union, for their contributions to the text. 


\section{Abbreviations}

$\begin{array}{ll}\text { ALDE } & \text { Alliance of Liberals and Democrats for Europe } \\ \text { CSPEC } & \text { Confederation of Socialist Parties of the European Community } \\ \text { EFA } & \text { European Free Alliance } \\ \text { EGP } & \text { European Green Party } \\ \text { EP } & \text { European Parliament } \\ \text { EPP } & \text { European People's Party } \\ \text { GG } & \text { Global Greens } \\ \text { GPI } & \text { Global Party International } \\ \text { ICT } & \text { Information and communications technology } \\ \text { IDC-CDI } & \text { Centrist Democratic International } \\ \text { IDU } & \text { International Democrat Union } \\ \text { LI } & \text { Liberal International } \\ \text { MEP } & \text { Member of European Parliament } \\ \text { PA } & \text { Progressive Alliance } \\ \text { PES } & \text { Party of European Socialists } \\ \text { SI } & \text { Socialist International } \\ \text { TEU } & \text { Treaty on European Union } \\ \end{array}$




\section{Executive summary}

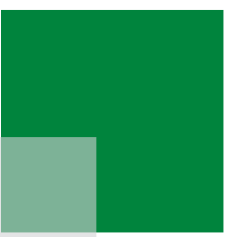

Democracy involves popular control over decision-making, as well as political equality among those exercising that control (see e.g. International IDEA 2017). In a parliamentary system, day-to-day control is delegated to elected politicians, who organize themselves in political parties. Political parties have become an important interface between the government and the people in many democracies around the world.

In recent decades the European Union has refined its democratic functioning by, for example, extending the decision-making powers and control of the European Parliament (EP) and facilitating the creation of European political parties. Given the multiple challenges to democracy worldwide, the EU must strengthen its legitimacy and accountability, and connect with citizens.

European political parties have come a long way but only recently established themselves at the heart of European democracy, a process that has paralleled the increasing attention paid to enhancing democracy and transparency in EU decisionmaking. European political parties play an important role, but face challenges in bringing messages to EU citizens and making them more aware of EU politics. In addition, the European institutional and electoral frameworks do not provide the same structure and tools for European political parties as their national counterparts are used to working with, which enable national parties to attract the attention and interest of citizens or to be featured in the media.

This Discussion Paper takes a comprehensive approach to understanding the role(s) of European political parties within the polity of the EU. Its focuses on how European political parties can (re)connect with EU citizens. The paper emphasizes the regulatory framework in which European political parties operate, their internal organization and the outreach in relation to various political actors, but especially citizens. It also considers ways to broaden, deepen and diversify how European political parties are able to connect.

The paper is structured as follows. Chapter 1 provides an overview of the political context, including recent developments, and analyses what is known about European political parties and why they matter. Chapter 2 takes a closer look at the legal and institutional framework in which European political parties operate, the role of national political parties, the rise of Euroscepticism and the linkages with citizens, individual membership of European political parties, the problem of representation 
and membership of the Global Party Internationals. Chapter 3 presents a set of recommendations to European political parties and stakeholders, including proposals to strengthen the role of European political parties and enable their engagement with EU citizens, and therefore enhance democracy within the EU. The Annex includes a proposal on transnational lists.

\section{Key recommendations}

The recommendations presented in this paper are primarily directed at European political parties, but also address EU institutions, national political parties, EU civil society, democracy supporters and citizens. Implementation can in some instances take place immediately (short term), while others require the adaptation of existing rules and/or the introduction of new ones (medium term), or treaty changes (long term). Overall, European political parties should play a larger role within (as well as outside) the 'Brussels bubble', especially during EP election campaigns and between elections.

\section{For citizens of the European Union}

- Improve EU education in school curricula throughout Europe, to promote citizen engagement in EP elections and their understanding of decisionmaking throughout the legislature.

\section{For national political parties and national authorities}

- Use Europarty logos next to national party logos on ballot papers, and ultimately only the Europarty logo, to improve the visibility of Europarties and of the EU dimension in EP elections.

- Endorse the election manifesto and political programme of the respective Europarty, and use these policy documents in election campaigns to increase understanding and visibility of Europarties, especially their endeavour to seek EU-wide compromise.

- Debate EU issues in national election campaigns and throughout the legislature to promote understanding of the impact of EU decision-making on national decision-making and citizens' daily lives.

- Separate EU and national elections to allow for distinct political debate at these policy levels.

- Transfer the power to select candidates (Spitzenkandidaten) to Europarties to reinforce their procedural role and visibility.

\section{For European civil society}

- Address policy memoranda directly to Europarties, and engage with them throughout the legislature. 
- Promote citizens' understanding of EU policymaking.

- Create initiatives to hold European leaders and institutions (such as VoteWatch Europe) accountable to all citizens, and lift the paywalls.

\section{For Europarties}

- Facilitate Europarty membership for individual citizens and improve their participation in Europarty decision-making.

- Rethink internal decision-making structures, and consider a greater role for individual members, majority voting and representation of party associations to improve internal democracy.

- Improve ideological homogeneity and strengthen relations with a single political group in the EP.

- Engage with civil society to enhance grassroots-level input in EU decisionmaking and to improve connections with civil society in daily party life.

- Ensure that affiliated foundations reach out beyond the 'Brussels bubble' to improve outreach to citizens.

- Enhance social media presence by investing in the use of adequate information and communications technology (ICT) applications and by copying good practices worldwide in this field.

- Develop and maintain permanent forums for citizens to facilitate debates on EU issues.

- Organize primaries for the selection of Spitzenkandidaten to enhance democratic decision-making, visibility and transparency.

- Diversify ways to increase funding (e.g. membership fees) to allow for more visible outreach to citizens.

- Improve transparency of revenues and spending patterns to enhance understanding and legitimacy.

- Strengthen links with EP political groups to improve Europarty impact on daily decision-making.

- Strengthen European Council summitry coordination to enhance public understanding and visibility.

\section{For European institutions}

- Reconsider the reorganization of 'les lieux du politique' or working spaces (especially the EP) to balance better access to citizens with security concerns.

- Redistribute part of funding to Europarties in equal shares in order to redress imbalances between larger and smaller parties and to safeguard the democratic space at the EU level. 
- Consider reserving the increase in public funding to 95 per cent of their total income for newly established parties, and for a limited time period, to encourage them to search for alternative funding.

- Provide clear rules on joint activities between Europarties and their national member parties to allow for more interaction during European election campaigns.

- Introduce separate European election campaign grants with strict spending requirements to increase visibility and safeguard operational budgets.

- Reconsider, reform, and improve the legal and political citizen-oriented toolbox to ensure the link with EU citizens (public consultations, petitions, European Citizen Initiative).

- Consider merging the role of President of the European Commission with the President of the European Council.

- Provide greater clarity on the organization, impact and outcome of 2018 'democratic conventions'. 


\section{European political parties}

According to European Commission President Jean-Claude Juncker, 'Our Union needs to take a democratic leap forward' (European Commission 2017b). Never before has a Commission President dedicated so many words on, and referred so explicitly to, the role of European political parties, civil society and citizens in the framework of 'a more democratic Union'. Juncker referred to the role of European political parties in the 2019 EP elections, new rules on the financing of political parties and foundations, transnational lists, the Commission's Citizens' Dialogues and democratic conventions (European Commission 2017a).

It is unclear how many of these announcements will become formal proposals, yet the fact that they were mentioned signals a recent change in perceptions of how best to improve democracy at the EU level. While the Brexit referendum, rising populism, and challenges related to migration and terrorist threats produced a pessimistic atmosphere in EU circles and many EU capitals in 2016, confidence in European integration and its institutions, policies and future ambitions grew throughout 2017. Although leading politicians at the EU level have played a major role, the sudden change in mood (which some have dubbed a 'European Spring') is largely a product of the outcome of national elections in Austria (2016), the Netherlands (2017) and, particularly, France (2017) as well as improved economic performance and the stemming of migratory flows. Active support for the EU has been observed among individual citizens - protesting Brexit or campaigning for a pro-European candidate -as well as among new and non-traditional political movements such as Pulse of Europe and En Marche. Yet it would be unwise to overestimate this new wave of Euro-enthusiasm.

Apparently, European political parties have not (yet) played a significant role in this European Spring. Eurosceptics have of course criticized the renewed support for European integration, and parties at the national and European levels have tried to replicate or be part of Emmanuel Macron's success. In the run-up to the European Council of June 2017, the newly elected French president was conspicuously absent from the meetings organized by the major European political parties. However, his views on how to relaunch the integration project, including his democratic stance, have suddenly become a point of reference (European Commission 2017b).

Article 10(4) of the Treaty of Lisbon amending the Treaty on European Union and the Treaty establishing the European Community (Lisbon Treaty, 2007), the so- 
called party article, states that it is the role of European political parties to 'contribute to forming European political awareness and to expressing the will of citizens of the Union'. Their development, especially in relation to the affiliated EP political groups and alongside European political foundations, has been impressive, both legally and politically. For instance, together with their groups in the EP, European parties have enjoyed remarkable success against some member states and national political parties in the framework of the Spitzenkandidaten (candidate selection) system, such as helping to strengthen the connection between EU citizens' voting behaviour during EP elections and the European Commission. Yet their role is still largely invisible, and they have not always participated in recent relevant initiatives. In the run-up to the 2019 EP elections, this paper examines European political parties' role in (re)connecting with EU citizens.

\section{What are European political parties and what do they do?}

\section{Steven van Hecke and Wouter Wolfs}

Scholarly attention to European political parties has taken place in four main waves. The first wave took place during the high expectations, not to say euphoria, in the run-up to the first direct EP elections in 1979. During this period, the first European political parties were founded, and many scholars expected a breakthrough on the EU political scene, to the detriment of national political parties. The second wave came after the introduction of the original party article (138a) in the Treaty on European Union (TEU, Maastricht Treaty, 1992), which for the first time officially recognized the role of European political parties within the EU, against a backdrop of growing discontent about the European integration process. European political parties were increasingly analysed from a comparative political perspective, instead of as just another feature of the ongoing integration process. The third wave of interest emerged in the context of the EU enlargements to Central and Eastern European countries, and the establishment of a regulatory framework for these party federations. Scholars analysed internal party changes following these developments, such as an increase in the number of member parties and ideological heterogeneity, and the role of new European foundations linked to European political parties.

Recent developments have triggered a fourth wave that takes the existence of European political parties for granted, both legally and politically. Not only has the number of European political parties increased significantly since the first regulations, they have also developed internally and differently in response to the changing legal and political context. European political parties can at times be seen as predominant, as in the Spitzenkandidaten process, while in other instances they appear to operate only 'in the shadow of hierarchy'. This paper focuses on this kind of approach and looks ahead to the 2019 European elections and beyond, reflecting on likely developments and feasible deliverables. The following section is partly drawn from and reproduces earlier research on the issue (van Hecke 2010: 395-411).

\section{What are European political parties?}

These organizations are labelled European political parties, even if they lack the main characteristic of national political parties: participation in elections. National parties 
dominate the selection of candidates and the electoral competition of European elections, although further advancing the Spitzenkandidaten process and potentially establishing transnational electoral lists could expand the role of European political parties.

Since their inception in the second half of the 1970s, parties operating primarily at the European level have received a number of different labels, some with a specific (and sometimes normative) connotation. The term 'pan-European parties', for example, implies a supranational aspect suggesting that these party organizations are more than the sum of their parts. According to this perspective, European political parties should be developed into fully fledged party organizations and take up roles similar to their national counterparts. The term 'Europarties' has recently become popular, as has 'European political parties', which derives from 'political parties at European level', the official name in the Treaties (see TEU, article 10(4); 2016/C 202/01 TFEU; TEU Maastricht Treaty article 138a).

Academics commonly use the term 'transnational party federation' to refer to one of the three parts of the European party family, in addition to 'national political parties' and 'supranational party groups'. The term has two main implications. First, it emphasizes the fact that these parties are federations (i.e. they consist of various national political parties) and mainly operate as 'parties of parties' (umbrella organizations for their national member parties). Second, their components, member parties, are not fully integrated into a single organization, a Europarty, as is the case with the delegations of national political parties in the party groups of the EP. From the moment they are formed, party groups operate independently of national political parties and their delegations. In party federations, however, the political centre of gravity lies with the national member parties. The fact that supranational party groups are more developed than transnational party federations does not imply a normative bias, however.

Calling European political parties 'transnational' is essential, as it refers to the level between the national and supranational levels, for which a distinct and separate party organization has been established. In this paper, 'Transnational party politics' refers to the level at which the national (or intergovernmental) and the EU (or supranational) spheres overlap. In other words, they are 'multi-level' parties (Deschouwer 2006) that operate at both the national and European levels. At the same time, the transnational level reflects the dual character of the EUintergovernmental and supranational. Transnational party federations are involved with intergovernmental institutions (the Council of Ministers and the European Council), as well as supranational institutions (the EP and the European Commission) (see Table 1.1). Uniquely, they operate in both of the institutional circuits of the EU. They provide an important link between the national and EU levels, and between intergovernmental and supranational institutions. 
Table 1.1. Levels and their corresponding party organizations and political institutions

\begin{tabular}{|l|l|l|}
\hline Level & Party organization & Political institution(s) \\
\hline National & National political parties & National governments and parliaments \\
\hline Transnational & Transnational party federations & Council of Ministers, European Council \\
\hline Supranational & Supranational party groups & European Commission, European Parliament \\
\hline
\end{tabular}

Source: Van Hecke, S., 'Do transnational party federations matter? (... and why should we care?)', Journal of Contemporary European Research, 6/3 (2010): 398.

Transnational party federations are also collective units, albeit in a different way than national political parties and supranational party groups. National political parties are sometimes considered non-unitary actors, especially when addressing intraparty organizations, factions, tendencies or similar topics. A Europarty also consists of several intraparty actors, each of which can have a different view on the role that the European party organization should fulfil (Day 2014). Whereas national party leaders consider European parties to be facilitating bodies for networking, Members of the European Parliament (MEPs) see them mainly as support organizations for EP group work, while staff from the Europarty secretariats aim to strengthen their supranational party characteristics.

Transnational party federations exhibit even more non-unitary characteristics than national parties, in the sense that they are generally composed of (national) political parties. Membership is mostly restricted to national political parties, even though the statutes of transnational party federations contain provisions that extend membership to individuals. Therefore, the number of members varies for different reasons for transnational and national parties. For example, membership variations within transnational parties are related to the size of their member parties, which does not apply to national political parties. All members of a national (or local/regional) party are equal, and size (quantity) is associated with weight (influence). In theory, all member parties, small or large, operate independently. In practice, however, larger member parties are often stronger or have greater influence over policymaking. Another major factor is policy distance (including intra-policy distance). A large member party can be weak if it is located far from the ideological centre of its transnational party federation, for instance. Intra-policy distances reflect the degree of cohesiveness within transnational parties. This is important in a number of cases, for example when a transnational party federation drafts a party document or electoral manifesto that is intended to be binding for its member parties.

Transnational party federations are much more elite driven than national political parties. The leadership runs the party, and there is limited participation from partisans in the party's day-to-day work; transnational parties do not have an electorate, membership or rank-and-file actors, and (unlike national political parties) they have almost no direct links with society. The only exception is the slowly growing number of actors that comprise European civil society. Transnational parties are, therefore, not as embedded in society as national political parties. Like national political parties, however, transnational party federations have organized themselves 
around party families or familles spirituelles (von Beyme 1985), although not all of these families have been present from the early days of transnational party federations.

Since 2004, transnational party federations have had a legal status and have benefited from direct financing from the EP budget (European Parliament and Council 2003, 2014). In the period 2004-17, no less than 20 organizations were recognized as 'political parties at European level' and consequently received EU funding (European Parliament 2017); there are currently 16 (see Table 1.2).

The link with the supranational branch of the party family-comparable to political groups in the EP-represents a process of growing emancipation. European political parties become more independent from EP political groups by forming families. Before the introduction of direct European subsidies in 2004, most European political parties depended on their corresponding political group in the EP for staff, accommodation and resources. These subsidies have given the Europarties more independence, but this - together with the establishment of a large number of new Europarties - has complicated the relationship between the Europarties and the political groups (see Table 1.2). The clear one-to-one relationship between a Europarty and a political group that characterized the pre-funding situation is now rather uncommon. Some groups bring together MEPs from various Europarties, whereas the members of other parties are dispersed over several groups. Furthermore, every European election generates some disruptive effects: once the new EP is composed, the centre of activity - and, accordingly, media and public attentionshifts from the European political parties to the elected assembly and its groups (Bardi 2006). The composition of political groups, and especially the total number of members, affects their political weight within the EP. 
Table 1.2. Political parties at the European level and their political families, 2017

\begin{tabular}{|c|c|c|}
\hline Political party at European level & Political group(s) in the European Parliament & Political family \\
\hline European People’s Party (EPP) & $\begin{array}{l}\text { Group of the European People's Party (Christian } \\
\text { Democrats) }\end{array}$ & $\begin{array}{l}\text { Christian Democrats/ } \\
\text { Conservatives }\end{array}$ \\
\hline Party of European Socialists (PES) & $\begin{array}{l}\text { Group of the Progressive Alliance of Socialists and } \\
\text { Democrats in the European Parliament }\end{array}$ & $\begin{array}{l}\text { Socialists/Social } \\
\text { Democrats }\end{array}$ \\
\hline $\begin{array}{l}\text { Alliance of Conservatives and } \\
\text { Reformists in Europe (ACRE) }\end{array}$ & \multirow[t]{2}{*}{ European Conservatives and Reformists Group } & $\begin{array}{l}\text { Conservatives/ } \\
\text { Eurosceptics }\end{array}$ \\
\hline $\begin{array}{l}\text { European Christian Political } \\
\text { Movement (ECPM) }\end{array}$ & & Christian-Social \\
\hline $\begin{array}{l}\text { Alliance of Liberals and Democrats } \\
\text { for Europe (ALDE) Party }\end{array}$ & \multirow[t]{2}{*}{ Group of Alliance of Liberals and Democrats for Europe } & Liberals \\
\hline European Democratic Party (EDP) & & Centrists \\
\hline $\begin{array}{l}\text { Europeans United for Democracy } \\
\text { (EUD) }\end{array}$ & $\begin{array}{l}\text { Confederal Group of the European Left-Nordic Green } \\
\text { Left } \\
\text { Group of Alliance of Liberals and Democrats for Europe } \\
\text { Group of the Greens/European Free Alliance }\end{array}$ & Eurosceptics \\
\hline Party of the European Left (EL) & $\begin{array}{l}\text { Confederal Group of the European Left-Nordic Green } \\
\text { Left }\end{array}$ & Non-Socialist Left \\
\hline European Green Party (EGP) & Group of the Greens/European Free Alliance & Greens \\
\hline European Free Alliance (EFA) & $\begin{array}{l}\text { Group of the Greens/European Free Alliance } \\
\text { European Conservatives and Reformists Group } \\
\text { Confederal Group of the European Left-Nordic Green } \\
\text { Left }\end{array}$ & Regionalists \\
\hline $\begin{array}{l}\text { Alliance for Direct Democracy in } \\
\text { Europe (ADDE) }\end{array}$ & Europe of Freedom and Direct Democracy Group & $\begin{array}{l}\text { Anti-establishment hard } \\
\text { Eurosceptics }\end{array}$ \\
\hline European Alliance for Freedom (EAF) & $\begin{array}{l}\text { Europe of Freedom and Direct Democracy Group and } \\
\text { Non-Attached }\end{array}$ & Nationalist Eurosceptics \\
\hline $\begin{array}{l}\text { Movement for a Europe of Nations } \\
\text { and Freedom (MENF) }\end{array}$ & Europe of Nations and Freedom & $\begin{array}{l}\text { Nationalist/right-wing } \\
\text { Eurosceptics }\end{array}$ \\
\hline Alliance for Peace and Freedom (APF) & No corresponding group (Non-Attached) & $\begin{array}{l}\text { Ultranationalist far-right } \\
\text { Eurosceptics }\end{array}$ \\
\hline $\begin{array}{l}\text { Alliance of European National } \\
\text { Movements (AENM) }\end{array}$ & No corresponding group (Non-Attached) & $\begin{array}{l}\text { Ultranationalist far-right } \\
\text { Eurosceptics }\end{array}$ \\
\hline Coalition for Life and Family (CLF) & No EP representation & $\begin{array}{l}\text { Reactionary Catholic } \\
\text { Eurosceptics }\end{array}$ \\
\hline
\end{tabular}

Source: European Parliament, Directorate for Political Structures Financing and Resources, 'Grants from the European Parliament to political parties at European level per party and per year', October 2017, <http:// www.europarl.europa.eu/pdf/grants/Grant_amounts_parties_10_2017.pdf>, accessed 28 November 2018. Note: Parties listed from largest to smallest. Groupings based on the affiliations of individual MEPs to European political parties in the context of the distribution of Europarty funding by the EP, as included in the annex of the note of 5 December 2016 of the Secretary General of the European Parliament on the grant award decision for the financial year 2017. 


\section{What do European political parties do?}

Using Duverger's (1951) terms, European political parties were internally (rather than externally) created in the run-up to the first EP elections in 1979. The party groups that had existed since the 1950s took the lead in creating party organizations (see e.g. van Hecke 2006). Since then, European political parties have developed in terms of both organization and membership. There is longstanding consensus among scholars about the number and main features of the various phases of development, as well as the decisive role of the environment in explaining party change (Hix and Lord 1997; Kreppel 2001; Hix, Noury and Roland 2007; Bardi 2006; Ladrech 2006). Integration (institutional incentives) and enlargement (broadly understood as an increase in the number of parties) have been of paramount importance (Hix, Noury and Roland 2007) in each of these developmental stages. Niedermayer (1983) used a three-stage model to analyse the development of European political parties. He differentiated between a contact stage in which infrequent contacts between national parties do not require a permanent transnational structure, a cooperation stage with permanent interactions and an integration stage in which national parties transfer sovereignty over decision-making to the European party organization. Day (2014) also applied a three-stage model of Europarty development, although he acknowledged that the eventual point of arrival depends on normative assumptions about the role that the Europarty should fulfil.

Panebianco (1988) distinguishes between two empirically linked dimensions in the development of European political parties. First, institutionalization depends on an organization's degree of autonomy relative to its environment. European political parties are rather weak along this dimension, because they must respond and adapt to an environment that they are not able to control. Second, institutionalization relates to the degree of 'systemness' - the interdependence among subgroups that is made possible by the centre's control of resources. Given the primary importance of national political parties among its constituent elements, European political parties are not institutionalized in this way either. As the two dimensions are empirically linked this is not surprising. Indeed, an organization with a low degree of systemness will find it hard to become autonomous from its environment.

The normative benchmark that is often used for European political parties is the functions that national parties perform in the member states. However, when compared to the traditional functions of political parties, Europarties have a more limited role and political weight (see Table 1.3; Wolfs and Smulders 2018). 
Table 1.3. Functions of European political parties

\begin{tabular}{|c|c|}
\hline Function & European political parties \\
\hline 1. Structure the vote & $\begin{array}{l}\text { Limited, since European elections are 'second-order national elections', but can be improved through } \\
\text { Spitzenkandidaten process, EU transnational lists or Europarty labels for national member parties. }\end{array}$ \\
\hline $\begin{array}{l}\text { 2. Mobilization and } \\
\text { socialization of the } \\
\text { public }\end{array}$ & $\begin{array}{l}\text { Limited due to low recognizability of Europarties, but can be improved through Spitzenkandidaten } \\
\text { process, EU transnational lists, Europarty labels for national member parties and a more developed } \\
\text { individual Europarty membership. }\end{array}$ \\
\hline $\begin{array}{l}\text { 3. Recruitment of } \\
\text { political personnel }\end{array}$ & $\begin{array}{l}\text { Only through the Spitzenkandidaten process, and can be improved through the introduction of } \\
\text { transnational lists. }\end{array}$ \\
\hline $\begin{array}{l}\text { 4. Aggregation of } \\
\text { diverse interests }\end{array}$ & Limited, since few Europarties have built a network of civil society organizations. \\
\hline $\begin{array}{l}\text { 5. Integration and } \\
\text { shaping of public } \\
\text { policy }\end{array}$ & $\begin{array}{l}\text { Limited, since most Europarty manifestos represent the lowest common denominator of their member } \\
\text { parties, and the link with a political group in the EP can be ambiguous. This is especially true for larger } \\
\text { Europarties, as they often need to reconcile more diverse political opinions. For an improved policy } \\
\text { impact, more detailed party manifestos and a stronger link with a political group are desirable. }\end{array}$ \\
\hline $\begin{array}{l}\text { 6. Organization of } \\
\text { government }\end{array}$ & $\begin{array}{l}\text { Limited, since few Europarties have meetings to bring together their representatives in different EU } \\
\text { institutions. Summits should become an important activity of all Europarties. }\end{array}$ \\
\hline $\begin{array}{l}\text { 7. Legitimation of the } \\
\text { political system }\end{array}$ & Limited, since Europarties cannot provide a strong link with the EU political system. \\
\hline
\end{tabular}

Source: Wolfs, W. and Smulders, J., 'Party financing at the supra-national level: the example of Europe', in J. Mendilow and E. Phéllipeau (eds), Handbook of Political Party Funding (London: Edward Elgar, 2018).

The first function of general political parties is to structure the vote in elections through party labels. However, Europarties have only a limited electoral connection, since European elections are fought in national electoral districts, among national political parties. Indeed, the first European elections were 'national': candidate selection, issues, campaigns and other aspects took place at the national level. Reif and Schmitt (1980) define EP elections as 'second-order national elections' in the sense that they had little or no direct effect on the parties that were in government at the national level (as is the case with local elections). Reif (1984) later refined the concept of 'second-order national elections', particularly with regard to the electoral cycle and the timing of European elections. Elections that take place in the middle of a legislative term generate a vote sanction for government parties prior to first-order national elections. Because EP elections were for a long time considered second-order national elections, European political parties (and even EP groups) were seen as a posteriori party organizations. As national parties wield power in a number of ways, including by controlling the selection of candidates and the party group MEPs join once they are elected, they were always late. The Spitzenkandidaten system, however, has changed the aforementioned process, and provides European political parties with an a priori attribute (van Hecke, Wolfs and de Groof 2018).

The second function of political parties is the mobilization - or representationand socialization of the population: parties connect citizens to the political system, and foster their social attachment to that system. Such a function requires high party recognizability, but European political parties are not well known by the general electorate (Mair and Thomassen 2010; van Hecke 2010). A more developed Spitzenkandidaten process and transnational EU lists could significantly improve 
Europarties' visibility. National parties should also be more active in displaying their connection to a European political party in their communication, political programmes and campaign material. Political parties can also represent and socialize citizens by mobilizing them as party members or activists, which increases their affinity to particular parties and the political system in general. However, individual membership of European political parties is underdeveloped: only a few Europarties have introduced individual membership, or make ample use of political activists during campaigns (see also section 2.4 of this paper).

A third party function is candidate selection: political parties recruit political personnel and select political leaders. In the EU framework, two institutions are directly elected or appointed: the EP and the European Commission. However, European political parties have (almost) no role in the candidate selection process. The selection of political personnel is therefore not a key function of Europarties (Raunio 2006; Bardi et al. 2010). National political parties create the electoral lists for EP elections, and national governments propose candidates for the various posts of European Commissioner. This slightly changed during the 2014 European elections, when five of the largest Europarties put forward their candidate for president for the European Commission-or Spitzenkandidat-using different internal selection procedures (Put et al. 2016). Transnational electoral lists, composed by the European political parties themselves, would give European parties more influence over recruiting political personnel to EU institutions.

The aggregation of interests of various groups in society is a fourth function of political parties. Some European parties have a large network of affiliated civil society organizations, but this is more the exception than the rule. Therefore, most European political parties only weakly perform this function (Mair 2007).

This is also related to the fifth party function-the integration and formation of public policy. Parties try to influence policymaking on the basis of their ideology. Although European political parties are organized according to political ideology, they are internally more heterogeneous than most national parties. Consequently, their political programs and manifestos are usually rather short and undetailed. Moreover, the corresponding political groups in the EP do not always act in line with the positions of their Europarty. Some parties, for example, are represented by various groups in the EP, which raises questions about its ideological coherence. Stronger links with one particular EP group and the development of more extensive party platforms that are followed by its group and its member parties could significantly improve Europarties' ability to perform this function.

The sixth function of political parties is the organization of government: parties structure the relations between the legislative and executive branches. Three of the four largest European political parties have developed a tradition of organizing party summits that bring together representatives of their political family from different institutions. However, these meetings are mostly limited to an exchange of views, and do not facilitate a thorough coordination of positions. Moreover, only 3 out of 20 Europarties organize this type of summit.

The seventh function-legitimization of the political system-flows from the previous six: parties connect citizens to the political system. Since Europarties fulfil the different functions only to a limited extent, they cannot provide a strong 
legitimization for the European political system. The further development of European political parties is required to enable them to form a strong link between European citizens and EU institutions.

European political parties have demonstrated a remarkable adaptability to alter their organization and, even more significantly, to incorporate a large and diverse number of new members, from both new and old member states, despite their being caught for a long time in second-order elections, and the above-mentioned reservations regarding the functions they perform. As a result, their size, strength and policy distance have become more complex. This has even become the rule, as European political parties require representation in a number of EU member states in order to be recognized. Similarly, changes in EP rules have made it impossible for single-party groups to be recognized as official groups. As 'rational, purposive organizations', similar to national political parties, 'they obviously have considerable incentives to mould the institutional opportunity structure in their favour' (Luther and Müller-Rommel 2002: 340).

The study of European political parties has been part of a tradition within comparative politics that views the EU as a developing political system (Bardi 2002: 294). This comparison with political parties at the national level has both advantages and disadvantages. One disadvantage is that by making national political parties the dominant unit of comparison, this analogy is 'caught' within the state-centric paradigm. Therefore, in areas such as organization, policy formulation, interest representation, media access and staff, European political parties were considered weak. However, the analogy is also advantageous as it allows the study of European political parties to benefit from numerous insights and findings about national political parties, such as party financing and MEP voting behaviour, which have developed within the field of comparative politics.

\subsection{Do Europarties matter?}

\section{Karl Magnus Johansson}

In addition to providing a nuanced definition and detailed account of their functions, the material impact of Europarties should also be considered. This section explores the conditions under which Europarties can be expected to 'make a difference' or matter. What factors can be hypothesized to condition Europarty influence? This section is partly drawn from, and reproduces, earlier research on the issue (Johansson 2016, 2017; see also van Hecke 2010).

Europarties' influence and effectiveness largely depend on their capacity to mobilize 'their' heads of government for the party cause. Pre-summit meetings involving government/party leaders are a central aspect of this mobilization process. However, their significance appears to vary over time and across party families (Tallberg and Johansson 2008, 2010). And while Europarties may be able to secure the participation of their heads of government at pre-summit meetings, their lack of organizational capacities to facilitate and coordinate positions may decrease their influence. Nor can they effectively impose their views on or influence decisions taken at European Council summits - at which the EU's main policy orientations and decisions are agreed. Europarties have a limited capacity to influence national 
government leaders in these negotiations and have no formal powers to take binding decisions themselves (Johansson 2016).

Europarties are better able to influence European Council decisions when leaders from one party family outnumber those from other party families (Johansson 1999, 2002a, 2002b; Lightfoot 2005; Tallberg and Johansson 2008). However, numerical strength or superiority alone is insufficient to influence political outcomes in the European Council along party political lines. A Europarty's heads of government must also be mobilized for the joint cause. Holding more Europarty summits 'may be a necessary condition for influencing EU decision-making, but it is not sufficient by itself (Hix and Lord 1997: 186). Hix (2005: 187) notes that for parties to exercise general influence in the EU, 'translation from party strengths to policy outputs requires party actors in the same party family to cooperate, and winning coalitions to be constructed between different party families'.

So, arguably, the greater the dominance of a particular Europarty-that is, the relative strength of the party families, as well as their greater cohesion and capacity to mobilize-the more likely it is to influence the process and outcomes of European Council negotiations (Tallberg and Johansson 2008). Exploring party politics in the European Council theoretically and empirically, Tallberg and Johansson (2008: 1238) note that the theoretical hypotheses advanced 'may be refined to incorporate other factors, such as the domestic political context of heads of government (majority/minority government, coalition/one party government)'.

Domestic political factors shape Europarties' cohesion, mobilization and degree of influence. Hanley notes in the context of the European People's Party (EPP) that even though the group of national party and government leaders happens to agree about very fundamental aspects of policy and consult regularly, 'these leaders remain first and foremost national politicians, responsible to national electorates' (Hanley 1994: 197; see also Hanley 2008). Arguably, this concern about domestic politics, constituencies and elections is the central factor restraining Europarty influence. Essentially nation-bound institutions that are rooted in national societies, social cleavages and issue dimensions, political parties are likely to prioritize domestic over European concerns. It is difficult to create a unitary command and control structure within Europarties, as they are federative 'parties of parties', consisting of national member parties.

Accordingly, it is essential to take domestic politics into account when exploring how governments and parties act in the EU. However powerful heads of government may be, they do not have full control over the domestic context in which they operate. This highlights the impact of the interplay (and inherent conflict) between government and opposition, and the party-political battles and intra-government divisions that break out as a consequence.

Therefore, in order for Europarties to exercise influence, they must exhibit a certain degree of cohesion in the internal arena, effectively mobilize, and work within domestic constraints on national parties and leaders. One way to assess whether Europarties matter or 'make a difference' is to gauge the extent to which they attempt to mobilize and influence. In other words, to explore how Europarties, through their party networks, make efforts to shape political processes and policy outcomes. 
In conclusion, Europarties matter when they are in numerical ascendance, relatively cohesive and able to mobilize their networks of political parties and leaders. The following chapter explores the context in which they operate, including the regulatory framework, their complex relationship with national parties and the challenge of reconnecting to (and representing) EU citizens, with the rise of Euroscepticism and the 'untapped potential' of their membership in Global Party Internationals (GPIs). 


\title{
2. Improving European political parties' connection with citizens through regulation
}

\author{
2.1. Carrots and sticks, rules and loopholes: how to regulate \\ European political parties
}

\section{Wouter Wolfs}

Although the first European party federations were established in the run-up to the first direct EP elections in 1979, the EU regulatory framework was not developed until 2003. The legal groundwork was laid down in the Maastricht Treaty, which added a strong political dimension to the European integration project that until then was predominantly economic in nature. Following strong political pressure from the presidents of the three main party federations-Wilfried Martens (EPP), Guy Spitaels (Confederation of Socialist Parties of the European Community, CSPEC) and Willy De Clercq (European Liberal Democrat and Reform Party, ELDR)-a specific article on Europarties was included in the treaty text (Roa Bastos 2012). Article 10(4) states that 'political parties at European level are important as a factor for integration within the Union. They contribute to forming a European awareness and to expressing the political will of the citizens of the Union'. This reference provided a 'constitutional recognition' to the Europarties, but was mainly declaratory in nature; it did not constitute a sufficient legal basis to develop a comprehensive regulatory framework.

Nevertheless, political pressure allowed for the establishment of rules, including important provisions for EU funding for Europarties. The EP issued a resolution in 1996 - the so-called Tsatsos report - calling for amendments to the party article in the EU treaties, so that rules on the legal status and financing of European political parties could be introduced (European Parliament 1996). Furthermore, the Greek, Austrian and Italian governments called for a revision of the treaty article in the 1996-1997 Intergovernmental Conference that led to the Treaty of Amsterdam (1997-99). Although these attempts did not achieve their goal of changing the article, they created a narrative and pathway towards Europarty funding and rules (Day and Shaw 2003; Johansson and Raunio 2005). 
The Europarties themselves also continued to push for revising the treaty article. In December 1999, the presidents of four of the then five Europarties issued a statement that emphasized the need to strengthen these party organizations. In February 2000, the secretaries-general of all five parties published a working document that set out a common position on party funding rules. The five party presidents endorsed these proposals with a joint letter to the European Commission and encouraged the institution to take a legislative initiative (Day and Shaw 2003; Johansson and Raunio 2005).

The issue became more urgent when the Court of Auditors published a critical report on the finances of the political groups in the EP later that year. The court denounced the practice of political groups providing Europarties with accommodation, staff and resources. At that time, most parties were located in the EP with their corresponding political groups, and most of the party personnel were group staff members. The court emphasized that financial support for Europarties could not be taken from budgets intended to fund political groups. However, withholding such support would seriously jeopardize the organization and activities of the Europarties, which made separate EU funding for these organizations even more pressing (Wolfs and Smulders 2018).

In February 2001, the European Commission launched its legislative proposal on the statute and financing of European political parties. However, no agreement was reached in the Council of Ministers, and the negotiations collapsed at the end of the year (Johansson and Raunio 2005: 527). The Treaty of Nice (2001-03) provided a new opportunity for legislative action: the party article was amended to include a specific provision on party funding. The treaty provided a stronger legal basis for an EU regulation on the rules and funding of European political parties. Only three weeks after the treaty's entry into force, the European Commission launched a new legislative proposal. The EP and the Council built on earlier efforts to reach an agreement: the regulation was published in November 2003 and entered into force after the 2004 EP elections.

The regulation was amended in 2007 to permit separate funding for European foundations that are linked to Europarties. Since 2008, these political think tanks have also received grants from the EP. The regulation was more substantially revised in 2014. The main changes related to the control of European political parties and possible sanctions for misconduct. The 2014 revision also included the establishment of an independent authority to handle party registration and monitor compliance with the rules. In September 2017, the European Commission once again published a proposal to make minor changes to the definition of party membership and how EU subsidies are distributed among the parties (European Commission 2017c). In May 2018, the EP and the Council of Ministers agreed on the text, so it can be fully implemented by the 2019 European elections.

This regulatory framework for European parties follows the same rationale as party finance laws at the national level: it combines public funding (carrot) and rules to regulate party organization and activities (stick) (Scarrow 2011). Yet the motivation behind these EU rules and subsidies significantly differs from the rationale behind similar legislation ruling political parties in EU member states. Whereas at the national level it was historically seen as an instrument to combat corruption and to 
make party competition fairer, the reasoning at the European level was much more normative. The regulatory framework was considered to be a measure to build up the Europarties and create strong party organization at the EU level, which could help to overcome the EU's democratic deficit. The rules were not designed to make party competition more equal, but-more fundamentally-to establish political party competition (Wolfs and Smulders 2018).

Overall, regulation of internal party organization is relatively limited; parties have considerable flexibility (for a more extensive discussion, see Wolfs 2017). First, the rules rather loosely define the concept of a party, both ideologically and organizationally. The regulatory framework does not include specific ideological requirements: European political parties do not necessarily need to support European integration, and Eurosceptic parties are also eligible for EU funding. Second, parties are not required to be ideologically homogenous. By contrast, technical groups in the EP are no longer allowed, and MEPs must form political groups 'according to their political affinities'. European political parties are required to have a political manifesto that observes the EU's fundamental values, but no further conditions are imposed in this respect.

The rules include few organizational requirements. A Europarty cannot pursue any profits, and must have its seat in an EU member state. Participation in European elections is a third requirement, although the role of European political parties in these elections remains rather limited in practice. The national member parties draft the electoral lists, and the European elections largely represent the sum of 28 national elections. The Europarties themselves do not compete directly. Europarties can indeed campaign with a Spitzenkandidat-their candidate to become European Commission president-but in the last European elections in 2014, only 5 of the 13 Europarties nominated a top candidate. It therefore remains unclear how this particular condition is assessed.

The most challenging requirement for European political parties is to have sufficient EU-wide representation. In order to be eligible for EU funding, the Europarty must be represented in at least a quarter of the member states, either by members of European, national or regional parliaments, or by a national member party that has secured at least 3 per cent of the votes in the most recent EP elections. This requirement is interpreted rather broadly: members of an assembly that is not directly elected, such as the House of Lords, are also taken into account.

The regulatory framework contains no requirements regarding other organizational aspects. There are no specific provisions on the modalities of membership of European political parties; a European party can be composed of (a combination of) national political parties, individual politicians, citizens or civil society organizations. However, in order to reach the above-mentioned representational threshold of seven member states, only members of parliament and national parties are considered. Nor does the regulation encourage a strong link between a European political party and a political group in the EP. MEPs from one political group can be affiliated with different Europarties, and a European party can count MEPs from various political groups.

The main consequence of these rather loose provisions is that party life at the European level can become rather complicated and unstable. A one-to-one 
relationship between a Europarty and political group is the exception rather than the rule: only the two largest parties - the EPP and the Party of European Socialistshave a clear connection to their corresponding group in the EP. The party system is also characterized by significant cross-membership and membership volatility of M(E)Ps: members of the same EP group (or even the same national political party) are affiliated with different European political parties. The MEPs from the French Front National, for example, support up to three different Europarties. Some MEPs have even attempted to be affiliated with two different Europarties at the same time (Wolfs 2017).

The recent European Commission legislative proposal tries to make these party affiliations more straightforward and transparent. The representational threshold of seven member states will no longer be considered at the level of individual members of parliament, but at the level of national parties, which precludes cross-membership. The Commission also proposes requiring national parties to publish the symbol and political platform of their Europarty on their website. This will make the link between the national and European party level much clearer to citizens, which is particularly important in the context of European elections. However, the proposed revision provides no incentives to strengthen the connection between European parties and political groups in the EP. It will, for example, still be possible for a national party to be a member of a particular EP political group and be affiliated with a European party that does not correspond to that group.

The distribution of subsidies to European political parties follows a two-step procedure. First, the EP's annual budget stipulates the total sum for party funding. Second, this sum is divided among the parties according to the following formula: 15 per cent is distributed in equal shares, and 85 per cent is allocated in proportion to the number of MEPs that are affiliated with the Europarty.

Hence, the funding principle is different from the system that is commonly used at the national level. In most countries, the level of subsidies for each party does not alter significantly between elections. At the European level, however, the public funding for each party can fluctuate much more. If the total amount of Europarty funding considerably increases or decreases from one year to the next, or if the number of parties changes, this affects the level of funding each party receives. Since the introduction of direct EU subsidies in 2004, both the total sum and the number of parties have steadily risen (Figure 2.1). However, the funding procedure has slightly altered in financial year 2018. European political parties must register with the Authority for European Political Parties and European Political Foundations to be eligible to for EU funding. At the time of writing, only 10 Europarties were registered (see EP's Europa portal n.d.). 
Figure 2.1. Total amount of party funding (2017 prices) and number of Europarties receiving funding

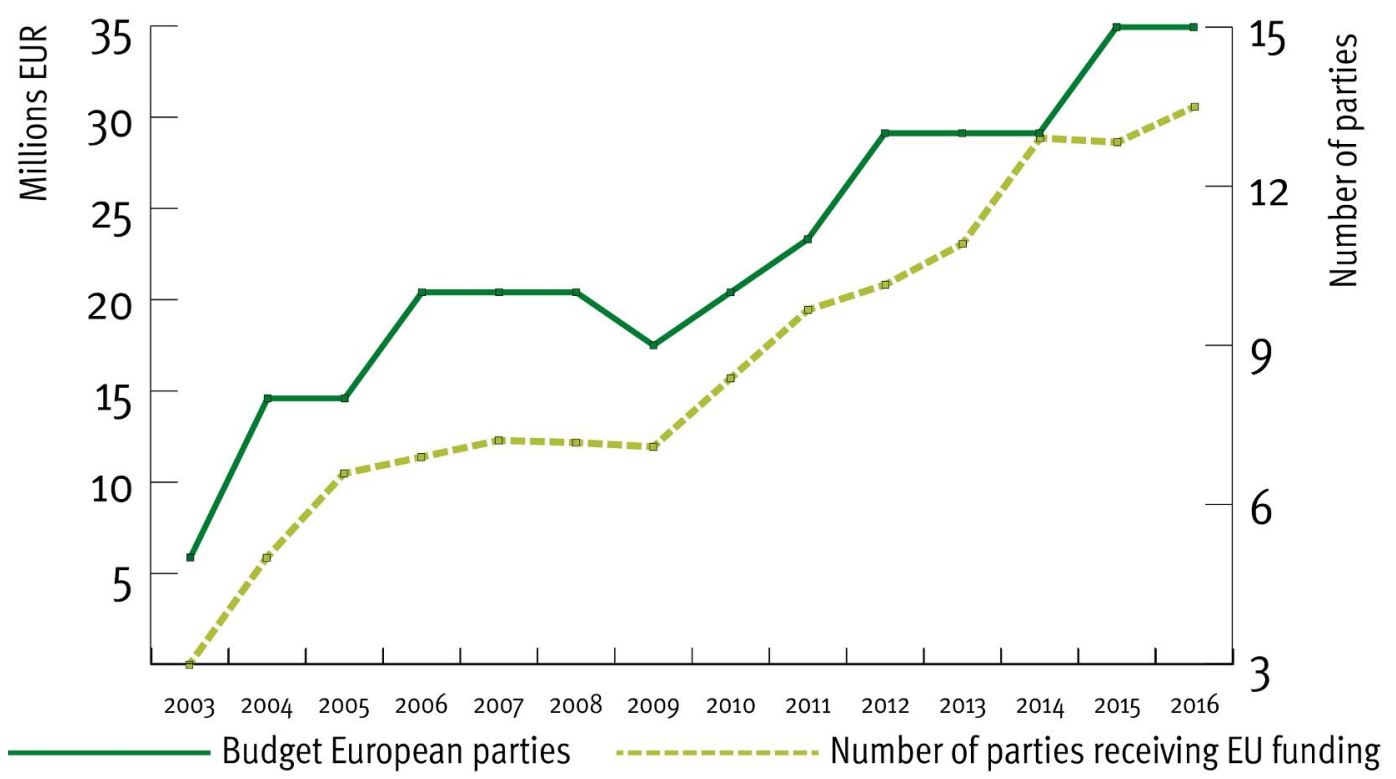

Source: Compiled by the authors based on European Parliament budget figures, 2004-16.

These European subsidies are clearly the most important source of income for European political parties, but the rules include a threshold on the amount of public funding a party can receive: a maximum of 85 per cent of the total party income. Therefore the parties must raise 15 per cent of their own resources (e.g. from individual members or member party donations) to 'match' the EU grant. Most parties manage to obtain their entire grant, but several smaller parties struggle to collect sufficient resources to match the public funding, which lowers their subsidies.

In its proposal to revise the regulatory framework, the European Commission has suggested changing the maximum level of public funding as well as the distribution key-to 5 per cent of the total sum distributed in equal shares and 95 per cent allocated proportionally. However, linking the distribution of funding to the number of affiliated MEPs risks making it more difficult for new and smaller parties to enter the system and to get their voices heard. The argument for a strict proportional distribution is stronger for political groups in the EP: it is important that they receive resources, speaking time, etc. in line with the share of the electorate they represent. Extra-parliamentary parties, however, fulfil a different role: they have to stimulate ideological debate at the European level, particularly in the context of the European elections. Therefore, it is important that smaller parties also have sufficient funds to bring their message to EU citizens. However, the lower the percentage of the total sum that is distributed equally, the more difficult it will be for smaller parties to get their voices heard.

Similarly, the European Commission is aiming to raise the ceiling for public subsidies from 85 to 95 per cent of total party income. This would make it easier for smaller parties in particular to receive their entire grant. However, increasing the 
ceiling reduces parties' incentives to strengthen their (financial) ties in society, and risks turning them into 'semi-state agencies' (Katz and Mair 1995).

The regulatory framework also includes provisions on how the European political parties can spend their public funding. Europarties cannot use their European subsidies to finance-either directly or indirectly-national political parties or candidates. Nor can they spend the funding on referendum or national electoral campaigns. In other words, there is a strict separation-in principle-between party funding at EU and national levels. However, European parties can co-organize events and activities with their national member parties. This is desirable if they want to raise awareness of the EU and connect to European citizens. But such co-organized activities blur the separation between the European and national levels and have involved the misuse of EU party funding; it is often difficult to determine when there has been indirect financial support.

This is particularly important with regard to the 2019 European elections. The rules allow European political parties to conduct their own European electoral campaigns, but in practice this often involves coordination and cooperation with their national member parties, as was the case in 2014. The stronger the link between the national and European party organizations-as is encouraged in the Commission proposal through publishing Europarties' symbols and programmes on national party websites - the more difficult it will be to differentiate between the campaign activities of the two organizations, which increases the risk of indirect financial support to national parties. However, the Commission proposal does not contain more provisions on joint activities and events, or clarifications on how the EU subsidies can and cannot be used. Therefore, clearer guidelines on party expenditure are needed for the upcoming electoral campaigns, particularly regarding joint campaign activities and events. The intended regulatory reform has its merits, but could go further in facilitating electoral campaigns that are more visible to citizens. EU decision-makers should also be aware that controlling the democratic debate on the future of the EU by discriminating against Europarties that go against the mainstream could jeopardize the legitimacy of EU institutions and EU democracy. Of course, the relationship with national political parties is not confined to these regulatory matters: there are interrelated institutional and political dynamics between the national, transnational and EU levels that directly affect Europarties' capacity to perform their functions.

\subsection{Punching above their weight? National parties and their Europarties}

\section{Gilles Pittoors}

Many current Europarties have a very similar organizational structure. Delwit, Külahci and Van de Walle (2004: 10) note that 'a kind of mimicry ... has had an effect in the structuring of European [party] federations'. Generally, Europarties are organized around a congress of representatives of their member parties, which forms the foundation of the party federation. Additionally, they have a central office that manages the federation's day-to-day activities. Finally, most of them also hold party leaders' meetings, pre-summits or summits, which bring together the leaders of both 
government and opposition parties across the EU. As such, the Europarty acts as the main coordinating institution connecting the national and European political arenas (Hix and Lord 1997). However, national parties must make a considerable investment in order to participate in this coordinative network, and they will only do so if they can ensure a proper return on this investment - that is, if they can maximize their influence on the policymaking process. Yet, national parties generally do not participate in the day-to-day management of the Europarty or even party politics in the European arena (Ladrech 2007). They instead focus their efforts on venues in which they can have a direct say on the policy positions of the Europartycongresses and summits. These two institutions are discussed in more detail below.

First, all Europarties regularly convene a party congress. Although their competences, voting procedures, membership and frequency vary to a certain degree, the congress is the principal institution of all Europarties' party federations. The Party of European Socialists (PES) statutes, for example, call the congress its 'supreme organ', while the EFA statutes refer to it as the organe souverain. Indeed, the congresses decide on some fundamental party issues: they elect the president (and other members of the central party office), nominate the Spitzenkandidat, approve the party's election manifesto and political programme, and often have the power to change the party statutes. Moreover, they bring together Europarty officials with national party delegates, MEPs, commissioners, heads of state and government, and sometimes even representatives of parliamentary assemblies of other international organizations such as the Council of Europe and NATO. As such, these congresses are the prime location for national parties, with their various backgrounds and ideas, to network with like-minded people and discuss the future of the Europarty. It is unclear, however, how national delegates engage in these discussions.

In particular, Klüver and Rodon (2012: 630) argue, it is important to 'evaluate how these ideologically diverse national member parties coordinate and arrive at a common position'. Their research has shown that Europarties do not simply adopt the median position of their member parties. Indeed, this only seems to be the case with the Alliance of Liberals and Democrats for Europe (ALDE) Party. The other Europarties in their study - the EPP, PES and European Green Party (EGP)—all diverge significantly from the median position. As with most joint decisions, therefore, coming to a common position in a Europarty would seem to be a matter of give and take. Put differently, national parties compete with each other in these congresses in order to ensure that the Europarty's position is as close as possible to their own ideal position. Applying Gamson's law to this process, Klüver and Rodon (2012: 633) argue that 'national parties' ability to succeed in this multilevel competition is determined by their legislative resource', which they define as 'the share of seats [national parties] control in the EP'. The logic is quite sound: the more a party can give in terms of legislative resources, the more it can take in terms of policy position. In short, larger parties weigh in much more than smaller parties. The results of their study support this claim: the outcomes of Europarty congresses are indeed 'skewed towards national parties with a larger seat share' (Klüver and Rodon 2012: 649).

These results are significant when considering the relationship between national political parties and their Europarty. Europarties exercise considerable influence over 
structuring the EU policymaking process, and particularly the partisan dynamics in the EP. They significantly limit the capacity of national member parties to develop an independent policy at the EU level. As a result, the policy position of the Europarty is very relevant to national parties' EU policies. However, Klüver and Rodon's research shows that parties are not represented equally within their Europarty. This is true regardless even of electoral success, because the number of EP seats is determined based on population size: 'parties from small member states are systematically disadvantaged in the political arena at the European level' (2012: 649). For example, an electorally unsuccessful German Social Democratic party might have more EP seats than an electorally successful Flemish Socialist party, and hence also more legislative resources and influence over the policies of the Europarty. This situation severely limits Europarties' representative capacities, and can become a serious issue for the democratic legitimacy of the EU should Europarties become increasingly important actors.

National parties, however, also have a second venue in which to ensure their influence: the summits preceding European Council meetings. While they have been around since the 1970s, summits have significantly grown in importance alongside the rise of the European Council, as they now mainly serve to prepare common positions among party families. Most summits bring together national heads of state and government, opposition leaders, commissioners and other relevant 'political personalities', thereby becoming 'the only political arenas where all the officials fulfilling executive functions at the European level from the same party family meet to discuss the medium- and long-term agenda of the EU' (Hix and Lord 1997: 65). As such, the summits are the only party institutions with sufficient 'political authority to agree credible and/or binding commitments about party behaviour at the national and European level' (Hix and Lord 1997: 66). Similarly, Tallberg and Johansson (2008: 1229) argue that, 'for the heads of government, the transnational parties offer a layer of coalition building in the European Council', whereby summits are central to a joint mobilization process.

More so than with the congresses, however, there are significant differences between Europarties' respective summits. While the EPP, PES and ALDE parties explicitly mention the existence of such meetings in their statutes and internal regulations, there is no mention of it in the statutes of the EGP, the EFA or any of the extremist Europarties-although the EGP is known to organize such meetings nonetheless. Hix and Lord (1997) point out that the quantity and quality of summits have increased over the years. They argue, moreover, that these meetings have actively set the medium-term policy agenda in the EU and have contributed to shaping alliance structures in the European Council. More recent work from both Tallberg and Johansson (2008) and Mühlböck (2013) has shown, however, that partisan dynamics in the Council remain rather rare. Tallberg and Johansson (2008: 1222) conclude that 'heads of government are seldom mobilized along transnational party lines', while Mühlböck (2013: 571) shows that MEPs and ministers from the same party 'hardly ever vote united'.

National party leaders therefore do not always seem to be highly committed to the Europarty and its summits. Indeed, Hix and Lord (1997: 66) argue that the large number of participants in these summits make private discussion among party leaders 
difficult, thereby defeating 'the original objects of the meetings'. As a result, party leaders have either ceased participating, or sought out other venues for direct discussion with a smaller group of party leaders. For example, Tallberg and Johansson (2008) report that former UK Prime Minister Blair considered these summits to be a 'complete waste of time'. Also within the EPP, there have been smaller regular gatherings of party leaders, such as the so-called Rheinland Group of German, Dutch, Luxembourgish and Flemish Christian democratic parties. More importantly, however, several scholars have shown that large countries have more power in the intergovernmental setting of the European Council. Faced with the limited success of Europarties in generating common positions among their heads of state and government, parties from small countries are again overshadowed by their larger peers.

In a way, the power imbalances within Europarties create a self-reinforcing logic. As small parties seem to be unable to have a significant impact on the positions taken by their Europarty in either the congress or the summits, they have no strong incentive to invest in participating in the Europarty's coordinative network. This, in turn, further limits both the Europarty's capacity to coordinate and the influence of small parties on EU policies. This brief overview therefore shows that Europarties face important internal and external challenges to their democratic function. Internally, they face a democratic shortfall because smaller parties and/or parties from smaller member states are underrepresented and dominated by the heavyweights. Consequently, externally Europarties are not in an ideal position to connect their policies with citizens. Therefore, Europarties need to settle their internal democratic mechanisms in order to be able to act as a bridge between the EU and its population.

\subsection{Reconnecting the EU with its citizens in times of crisis}

\section{Nathalie Brack}

Reconnection to EU citizens remains inherently complex to achieve when the European political and public sphere is so often dominated by Eurosceptic narratives. The Juncker Commission proposed a democracy package as one of its 10 priorities, and adopted legislative proposals to reform some instruments aimed at increasing citizens' participation in EU politics. Although the attempt is welcomed, this democratic concern is far from new. There have been numerous plans and strategies to (re-)connect Europe with its citizens, most of which have not been particularly successful, as demonstrated by the current distrust among EU citizens of the EU. Their failure is not surprising, given the complexity of the EU's 'democratic deficit' and the current internal and external context. The EU is facing a series of crises-at the political, social and economic levels-in addition to doubts and criticism regarding its democratic nature. The EU seems to have become a crisis manager, which is unable to put forward an ambitious and new strategy to deal with citizens' everyday concerns, or to promote their participation in EU politics. Yet the democratic challenges are not restricted to the EU: research and surveys show that citizens are increasingly dissatisfied with the way democracy functions at both the national and supranational levels, and that they increasingly mistrust mainstream 
political parties and democratic institutions (Armingeon and Guthmann 2014; Mair 2007). It therefore seems that challenges to democracy extend beyond the EU.

While dealing with all the interconnected issues in a broad and multifaceted debate on democracy in the EU is beyond the scope of this section, two elements are stressed here: (a) the rise of Euroscepticism and the democratic nature of the EU and (b) the disconnect between the supranational and national parties, and the limited role of Europarties.

\section{Engaging with Euroscepticism}

The rise of anti-EU sentiments is one of the most important trends following the integration process that has taken place over the last two decades (Usherwood 2007). Faced with economic and other crises, European integration has entered a new and more difficult phase, characterized by mass Euroscepticism, the rise of radical and populist parties, and the mainstreaming of anti-EU rhetoric (Brack and Startin 2015; Vasilopoulou 2013). As a result, the expression of popular discontent during the 2014 EP elections through, among others, the election of a higher number of Eurosceptic MEPs, was unprecedented. The EU's scope of intervention, as well as its legitimacy, has been increasingly challenged, especially on economic governance. The context of democratic malaise and economic crisis had provided fertile ground for the mobilization of populist and Eurosceptic parties that could exploit the prevailing sense of disconnect and hostility at the 2014 EP elections. The share of pro-EU groups in the EP declined, while the number of dissenting voices grew significantly. Euroscepticism therefore seems a permanent fixture that cannot be reduced to 'the ignorance of the people' about EU issues (Usherwood and Startin 2013). If the EU intends to deepen its democratic character, it is time for its institutions and for mainstream political parties to hear the arguments of Eurosceptics, and to engage in a constructive deliberation with dissenting voices, rather than systematically discredit their positions. More concretely, the reform of Europarty funding, as included in the recent European Commission proposal on the regulation on European political parties and foundations, would restrict EU subsidies to parties that are committed to European integration. Such a change goes against a primary principle of democracy - the assurance of a healthy democratic debate. It would be detrimental to party competition and to a healthy democratic debate on one of the two main cleavages found at the EU level, the pro-/anti-EU divide (Hix, Noury and Roland 2007; Otjes and van der Veer 2016). EU institutions have proven to be resilient to crisis, and should therefore be mature enough to allow a diversity of points of view, including an anti-system minority. Using funding rules to hinder the development of Eurosceptic transnational parties is likely to backfire in terms of democratic development, and to fuel criticism of the EU's lack of democratic legitimacy.

In addition, research shows that the presence of Euroscepticism within EU institutions could help alleviate the democratic deficit of the EU, for example by increasing its representativeness and demonstrating that the EU is open to debate and dissent. But it would require EU institutions to engage with sceptics, and to use the EP as a true forum for contestation (Brack 2015, 2018; Usherwood and Startin 2013). 


\section{A better connection between European and national political parties}

The 2014 EP elections represented an important milestone for the EU. For the first time, there was a direct link between the vote in EP elections and the nomination of the President of the European Commission (Schmitt, Hobolt and Popa 2014). Most political groups nominated a lead candidate under the slogan 'this time, it's different': this new opportunity was expected to rouse the public's interest, to bridge the gap between the EU and voters, and to reduce the second-order nature of these elections. However, these elections remained, in most member states, second-order national contests.

Thus far, EP elections have been nationally based, with national parties as key actors: they select their candidates and control the campaigns, usually focusing on national rather than EU issues. Moreover, the achievements and work of MEPs during the previous legislature are rarely taken into account when national parties compile their electoral lists. And although there is an increasing link between national and EU politics, national parties remain dominant. European parties should be strengthened as an essential link, and central interface, between EU institutions and citizens, through representative democracy. National parties could become more engaged by formally endorsing their Europarty manifesto during EP election campaigns, and rules on EU campaigning could be streamlined to give a more prominent role to Europarties. More importantly, Europarties need to be more visible on the national political scene.

\subsection{Europarties and their grassroots members: an opportunity to reach out and mobilize}

\section{Isabelle Hertner}

Europarties are still unknown to most European voters. Few will have heard their names, or would recognize their symbols. There are a number of explanations for their invisibility. First, all major Europarties have their headquarters in Brussels, where they often organize meetings and conferences for the representatives of their national member parties. Without specific knowledge of the dynamics and actors within the 'Eurobubble', citizens are unlikely to come across Europarties' politicians, offices or even campaign posters. Second, all the major Europarties remain 'parties of parties' (Johansson 2009). National member parties tend to have the last word on issues from electing party leaders to writing and ratifying Euromanifestos. National parties will not be inclined to relinquish the privilege of these powers. It is therefore not surprising that most national political parties fail to highlight their Europarty affiliation. Indeed, even some of Europe's biggest national parties do not use Europarty manifestos or other Europarty campaign materials such as posters during EP election campaigns (Hertner 2011).

Europarties are aware of their relative invisibility, and seek to address it. A recent attempt to directly reach voters has been to open Europarty membership to individual citizens. Under different terms and conditions, all the major Europartiesincluding the EPP, the PES, the EGP, the Alliance of Liberals and Democrats for Europe, and the Party of the European Left-have introduced individual membership. This section highlights how individual membership can benefit the 
Europarties, their national member parties, and the individual members themselves. Only when mutual benefits are tangible can individual membership be successful in the long term.

\section{How Europarties can benefit from individual members}

Research on national political parties has highlighted that party members are a valuable resource (Scarrow 2015). For instance, a large membership provides parties with democratic legitimacy. Members might also pay fees, which can help parties to finance their expenses. But crucially, members do most of the 'donkeywork' during and beyond election campaigns: they distribute leaflets, put up posters, man stalls on local high streets, knock on doors, make telephone calls, and promote the party on social media. Therefore, while having a network of online supporters and occasional volunteers is important for national parties, 'traditional' members still carry out most of these tasks (Webb, Poletti and Bale 2017; Scarrow 2015). For Europarties, individual members can be just as important. After all, EU-savvy campaigners who think and act across borders, understand the EU, and are happy to discuss it in an informed manner are in short supply at the grassroots level. Many national parties invest little in their grassroots' EU knowledge and awareness (Hertner forthcoming). ALDE's 'individual members', the 'PES activists' and the EGP's 'individual supporters' have broadly demonstrated their willingness and ability to campaign across Europe during European and national elections, and might well contribute to filling the wide EU gap at the grassroots level.

However, many national parties are reluctant to empower individual Europarty members because they worry about losing their pole position within Europarties. They also seek to remain in charge of membership selection and administration. However, with the steady decline in turnout for EP elections (Franklin and Hobolt 2011), and the decline in party membership across Europe (van Biezen, Mair and Poguntke 2012), national parties might have to open their minds and doors to those people who campaign for Europarties directly.

\section{What's in it for the individual members?}

Individuals obtain different benefits or rewards from joining political parties. There is no reason to assume that the benefits obtained by individual members of Europarties are significantly different from those of national party members. One can therefore assume that most individual members join a Europarty because they want to participate, and make a difference. They also want to meet like-minded people with whom they can socialize and discuss politics, especially when they have a special interest in EU matters. For some individuals, Europarties also offer an ideological home that is not available in their own country. For instance, ALDE and the EPP offer individual membership to citizens living in countries with no ALDE/EPP member party.

\section{Europarties: Wake up!}

Therefore, if Europarties are to be effective at attracting (and keeping) individual members, in order to build up a mass membership, they would need to grant them rights, such as the right to participate in policymaking and the selection of leaders. 
Many national parties across Europe have opened up their decision-making processes to members (Gauja 2013), and Europarties could do the same. So far, progress in this direction has been rather slow. Among all Europarties, ALDE has gone the furthest by granting a number of selected individual members the right to vote at the party congress, which is their highest organ and ratifies manifestos. ALDE also allows one elected individual member to attend meetings of the Council, which is its secondhighest organ and is responsible for approving membership applications, membership fees, the party's annual budget and accounts, and nominating the secretary general. The PES and EGP allow their individual members to participate in the party's debates, but do not give them voting rights at the congress. It is, however, worth highlighting that the EGP organized open primaries in the run-up to the 2014 European elections, which gave individual supporters the opportunity to vote for the two Green Spitzenkandidaten.

According to the so-called party article, it is the role of Europarties to 'contribute to forming European political awareness and to expressing the will of citizens of the Union'. This enormous task could be made easier if citizens were given the opportunity to be directly involved in Europarties. Such involvement could be achieved through a system of delegation and representation, whereby individual members elect among themselves a number of representatives to attend party congresses and other relevant party bodies, where they have the right to vote. At a time when memberships are ageing and shrinking, parties should more than ever have an interest in reaching out and mobilizing new supporters.

\subsection{Can the representative and procedural roles of the Europarties be fulfilled at the same time?}

\section{Wojciech Gagatek}

The title of this report-Reconnecting European Political Parties with EU Citizensconstitutes a fundamental normative challenge: what is expected of European political parties? This section explores questions including What kinds of roles should they play? And if they are expected to reconnect with EU citizens, what about their procedural role? Can representative and procedural roles be reconciled?

The idea that Europarties should reconnect with EU citizens resonates with an idealist vision of mass party politics, which was popularized during a time when parties first and foremost represented citizens. They were treated as a part of civil society, a transmission belt between voters and the government, standing clearly on the voters' side (Duverger 1951). However, that era (if it ever really existed) has long since ended (for a review, see Dalton and Wattenberg 2000). The rise of cartel parties (Katz and Mair 1995) has significantly reduced their representative role, focusing instead on their procedural function and their place within the state structure, therefore becoming semi-state agencies or public utilities (van Biezen 2004). As such, citizens do not treat them as a part of civil society (Mair and Thomassen 2010). The contrast between these party models is quite telling. Therefore, if national parties no longer connect with citizens, and if citizens expect them to govern rather than represent them, why should Europarties be expected to engage in a representative role aimed at EU citizens? 
One of the answers to this question emerges from the debate over Europarties that began in the 1990s. Given the growing public scepticism at that time, there was much discussion in the EU on how to get closer to citizens. The expectation that Europarties could play a role in this endeavour is visible in the discussions surrounding the adoption of Regulation No. 2004/2003, which introduced public funding for Europarties from the EP's budget (Gagatek 2014), or similar discussions about the role of European political foundations, affiliated with Europarties (Gagatek and van Hecke 2014). In short, Europarties were framed into an EU public sphere that would be created if citizens could be more informed about what the EU was. The main targets were citizens, who should be educated on what the EU is and what it does, rather than voters or sympathizers, who should be convinced to support a certain vision (one of many) about what the EU should be. In this way, Europarties were expected to engage with functions typical of those fulfilled today by civil society organizations.

Since the mid-2000s, the focus has partially moved towards discussing the pros and cons of politicizing European integration (Hix and Bartolini 2008). In a nutshell, the idea was that citizens do not understand, or engage in, EU politics because it lacks the political controversy that marks national politics. Mainstream Europarties represent a unified pro-European political front, and all emphasize the benefits of European integration. EP elections do not matter that much; they also have no impact on the partisan composition of the European Commission. One way to change this state of affairs would be to politicize the European Commission, for example by making the election of its President dependent on the result of EP elections. Such a reform would create a role for Europarties, as they could create the conditions for, and execute, the process of nominating their lead candidates for the job of Commission President (Hix 2008).

The intentional role of Europarties has moved from being part of an EU civil society to manifesting different political views on the left-right spectrum and different views on the current state and future of the EU, in order to engage the interest of voters and bring the EU closer to them. This implies that they are not simply (re)connecting with citizens, but rather with voters or sympathizers: the individual members of their national political parties, or their own individual members, in the same way as their national counterparts do. This represents a return of the idea that political parties are not primarily a part of civil society, but a channel of the aggregation and representation of political ideas.

Can these two roles be achieved at the same time? In other words, can Europarties be expected to better connect with their 'voters', supporters or even the whole citizenry, while being more effective in their procedural roles (i.e. having a greater influence on EU politics)? The experience of recent decades in party politics at the national level has shown that when parties increase their engagement in fulfilling their procedural roles, their representative functions diminish to some extent. From this point of view, Mair and Thomassen (2010) have argued that the fact that there is no party government at the EU level, and that there is less room for engaging procedurally, create the conditions for Europarties to effectively fulfil their representative tasks. But how do Europarties and their national political parties look at this? Is it rather the result of expectations imposed on them, fitting the broader 
objective of bringing the EU closer to its citizens and building a European civil society?

For this reason, one should be cautious about imposing functions on Europarties, as they are unlikely to fulfil these if such a demand does not exist internally, or within their national member parties. Europarties should remain free to choose the best strategy to achieve their most important goal: to become relevant to their own national member parties, and to show the added value of transnational party cooperation. This applies to both pro-European and Eurosceptic political parties at the European level. Some Europarties might recognize the benefits of stressing their representative roles, and they should be free to engage in such activities. But if others have another approach, they should not be forced to go in this direction.

This does not mean that, in principle, there are no ways to reconnect with citizens. By way of illustration, since the 2009 EP elections, the PES has been challenging the larger EPP not only on programmatic grounds, but also in relation to the question of which party is more internally democratic and inclusive, therefore claiming to allow greater input from individual citizens, rather than from member parties (Gagatek 2009). A few Europarties introduced ways for individual sympathizers to directly engage in their activities. In 2014, the EGP initiated a revolutionary process of an open, online primary to select its Spitzenkandidaten for President of the European Commission. However, other parties preferred traditional, delegate-based ways to select a candidate, in which only national member parties had a say (Put et al. 2016). Still, even if some Europarties are consulting individual citizens on who should be their leading candidate, this is because of developments in their procedural, rather than representative, role.

For this reason, Bardi et al. (2010) argued that Europarties could become a transmission belt, an intermediary between the national polities and supranational institutions. One key example would be to propose and collect signatures in favour of a European Citizens' Initiative (ECI; see European Commission n.d.). So far, these initiatives have primarily come from civil society organizations, but if Europarties are to reconnect with citizens (and indeed, if one recalls the expectations formulated against them regarding their place within civil society), there is no reason why they should not show their relevance as actors able to propose and coordinate the collection of signatures. If, however, one argues that this instrument should be reserved for other civil society organizations, then perhaps the Europarties, like their national counterparts, should focus on their (prospective) procedural roles and leave the representation of citizens to others.

\subsection{What can Europarties learn from national political parties?}

\section{Emilie van Haute}

Europarties do not always play the same role and perform the same functions as national parties. One tempting recommendation would be to make European party organizations look more like national party organizations, and perform increasingly the same functions. Research shows, however, that national parties are also facing more and more difficulties in performing their role in representative democracies. While national parties increasingly become public utilities (van Biezen 2004), 
dependent on the state, rather than voluntary civil society organizations, they face growing difficulties in maintaining their link with civil society. This affects their capacity to facilitate representation and participation. In particular, citizen mobilization via membership and activism are a challenge (van Haute, Paulis and Sierens 2017).

Rather than mimicking national party organizations, Europarties can learn from national parties that have engaged in internal reforms in an attempt to overcome these challenges (Scarrow 1999). These reforms have predominantly focused on two dimensions of party organizations. First, parties have opened up their decisionmaking processes by extending the selectorate (i.e. the body of individuals allowed to take part in major intraparty decisions such as leader or candidate selection) or manifesto adoption (Rahat and Hazan 2011; Cross and Katz 2013; Cross and Pilet 2016; Gauja 2017). Here, there is a general shift from a delegation model (in which party delegates are granted rights) to a one-member-one-vote model (where all party members are granted these rights). Some parties have extended these rights beyond the party boundaries (e.g. via voters' primaries). Second, parties have engaged in reforms that are blurring the contours of their organization. They have developed alternative affiliation options such as supporters, sympathizers or other forms of 'membership light' (Scarrow 2015).

Have these reforms managed to solve the linkage issue and to reconnect parties with civil society? Kosiara-Pedersen, Scarrow and van Haute (2017) show that parties that offer more rights to their members in their decision-making process, and that charge lower membership fees, tend to have more members. Conversely, when membership is relatively costly (higher fees), those who do join are more likely to use their membership by being active in the party (Kosiara-Pedersen, Scarrow and van Haute 2017). There can, therefore, be a trade-off for parties between qualitative and quantitative participation. Besides, parties that develop alternative affiliation options tend to have less traditional members. Offering more rights to members therefore only encourages more members to join if they do not have an alternative affiliation option. Achury et al. (2018) show that parties that grant more rights to their members tend to have a more representative membership base, both socially and politically.

These reforms produce effects that go beyond participation and representation (linkage). Comparing decision-making processes within parties, researchers show that granting rights to more inclusive selectorates (such as party members or voters), as opposed to party delegates, can decrease the representativeness of the output of the decision (leader/candidate/manifesto). It can also decrease the competitiveness of the selection processes, favour incumbent candidates, and present challenges to responsiveness and intraparty cohesion (Rahat and Hazan 2011; Cross and Pilet 2016; Gauja 2017). There can, therefore, be a trade-off between a more democratic input (more participation) and a more democratic output (the outcome of the decision-making process).

Finally, are these reforms a sign of the democratization of political parties? The dominant view correlates more open decision-making processes (in which rights are granted to rank-and-file members or voters) with more democratic processes and intraparty democracy. This illustrates a participatory model of democracy that 
champions citizens' direct involvement in the decision-making process. At the system and party levels, reforms are undertaken to develop more participatory tools that empower citizens and grassroots members. Such reforms tend to discredit other models of democracy, such as representative democracy, which rests on the principle of a chain of delegation in the decision-making process. Parties are at the heart of the delegation process and representative democracy. Therefore, undertaking these reforms might indirectly widen the gap between citizens and parties.

\subsection{Global Party Internationals: 'tackling the dilemma of indifference'}

\section{Stephen Day}

The final dimension of strengthening Europarties' relevance, impact and effectiveness is to ensure that they are able to attain and engage with the global arena beyond the confines of the EU. This is most likely to be achieved by Global Party Internationals (GPIs), longstanding global structures of party-political cooperation that have waned in significance, but that may still constitute a useful tool for Europarties (see Table 2.1). As explored below, there is an (albeit limited) 'untapped potential' (Hällhag 2008) that could broaden and therefore enhance the representation functions performed by Europarties. GPIs could also enhance the EU's role as a global actor, a domain in which the EP and Europarties tend to be sidelined.

On hearing the term 'Global Party International' (GPI) what sort of image does it conjure-up and what sort of expectation does it evoke: Internationalism and solidarity? A sense of romanticism? Global-level agenda setting? A relic from a bygone age? An irrelevance? Exploring this story, it soon becomes apparent that a duality of 'capacity' (the empirical dimension) and 'expectation' (the normative dimension) are an essential part of the narrative surrounding the GPIs. This duality also underpins what is defined here as the 'dilemma of indifference'. This is a scenario where advocates for enhancing the transnational and supranational qualities of GPIs inadvertently stoke a sense of indifference because their aspirational desires find it difficult to fit with national realities; while those who hold a general dismissiveness towards the GPIs start from a premise of indifference. How might the GPIs face up to this conundrum, remembering that it may well have to be embraced rather than solved? It seems that the starting point has to be a recognition of 'what is' rather than 'what might be'. For example, unlike the Socialist International (SI), Liberal International (LI) and Centrist Democratic International (CDI), the Progressive Alliance (PA) (and, to some extent, the Global Greens, GG) seeks to herald itself more in terms of a network rather than in terms of a 'party'. 
Table 2.1. The Global Party Internationals

\begin{tabular}{|c|c|c|}
\hline Party international & Founded & Key documents \\
\hline $\begin{array}{l}\text { Socialist } \\
\text { International (SI) }\end{array}$ & $\begin{array}{l}\text { 1951-Secretariat based in London. Talk of a 'House of Social- } \\
\text { democracy' with the Party of European Socialists (PES), in Brussels } \\
\text { in the late } 2000 \text { s, came to nothing. }\end{array}$ & $\begin{array}{l}\text { 'Aims and Tasks of } \\
\text { Democratic Socialism', } \\
\text { Frankfurt, } 1951 \\
\text { 'Stockholm Declaration', } 1989\end{array}$ \\
\hline $\begin{array}{l}\text { Liberal International } \\
\text { (LI) }\end{array}$ & 1947-Secretariat based in London & $\begin{array}{l}\text { 'Liberal Manifesto', Oxford, } \\
1947 \text { and } 1997 \\
\text { 'Liberal Manifesto', Andorra, } \\
2017\end{array}$ \\
\hline $\begin{array}{l}\text { Christian/Centrist } \\
\text { Democrat } \\
\text { International (CDI) }\end{array}$ & $\begin{array}{l}\text { 1961-Formerly the World Union of Christian Democrats; then the } \\
\text { Christian Democratic International. Present name since } 2001 . \\
\text { Secretariat based in the HQ of the European People's Party, } \\
\text { Brussels. }\end{array}$ & $\begin{array}{l}\text { ‘CDI Basic Plan’, Brussels, } \\
1995\end{array}$ \\
\hline $\begin{array}{l}\text { International } \\
\text { Democrat Union (IDU) }\end{array}$ & $\begin{array}{l}\text { 1983-Alternating Secretariat. Initially UK Conservative Central } \\
\text { Office. Relocated to Oslo (2005). Presently in the CSU HQ, Munich. }\end{array}$ & $\begin{array}{l}\text { 'Declaration of Principles', } \\
\text { London, } 1983\end{array}$ \\
\hline Global Greens (GG) & $\begin{array}{l}\text { 2001-Started with a virtual presence. Secretariat now at the EGP } \\
\text { HQ, Brussels. }\end{array}$ & ‘Global Green Charter’, 2001 \\
\hline $\begin{array}{l}\text { Progressive Alliance } \\
\text { (PA) }\end{array}$ & 2013-Coordinating office located in the SPD HQ, Berlin. & $\begin{array}{l}\text { ‘Guiding Principles: } \\
\text { Progressive Alliance for } \\
\text { Freedom, Justice and } \\
\text { Solidarity’ [n.d.] }\end{array}$ \\
\hline
\end{tabular}

Therefore, once the GPIs are looked upon as entities in a state of becoming, where the prospect of an ever-permanent vestigial status is very real, it becomes possible to dampen expectations without dismissing them out of hand. From there, one can begin to think about the sorts of strengths, weaknesses, opportunities and threats that accompany the GPIs, alongside some future-oriented action points. The aim here is to determine whether it is possible to challenge those parts of the narrative that have been shaped by indifference.

\section{Key characteristics}

For decades, political parties all over the world have sought membership of their corresponding GPIs. Central to the identity of a GPI is their make-up as an 'association of national political parties' (that also includes the presence of regionalbased party federations such as the Europarties) and the belief that their ideology has a transnational reach. As Dr Alois Mock declared at the 1983 inauguration of the International Democrat Union (IDU): 'political ideas have no national frontiers' (IDU 1983: 2). In addition, underpinned by internationalism and solidarity, the GPIs seek to project themselves on the international stage. The LI, for example, stresses that its purpose is 'to win general acceptance of Liberal principles which are international in their nature'. The CDI, LI and SI all hold a consultative status at the UN Economic and Social Council, although it is difficult to find out what this entails, and what impact (if any) they might have had. To translate identity into action, the GPIs also seek to foment a sense of purpose with an intention to play a role. This has manifested itself in a lexicon of organizational self-ascription that includes: 'federation', 'network', 'association', 'partnerships', 'working cooperatively' and 'mutual support'. 
However, capacity-wise, the opportunity to live up to and actualize that selfascription remains dependent on national member parties believing that their GPI is worth investing in. Their capacity to follow through with initiatives often appears wanting. However, given that they operate on a shoestring budget, via an extremely small secretariat (where many of the handful of staff are volunteers), this is not surprising. More recently, in a bid to further cut costs, a number of GPIs relocated to the same address as their Europarty counterparts in Brussels where they are registered as international non-profit organizations. Others have set up offices in the headquarters of one of their national member parties. Does this constitute a realworld relevance or irrelevance?

During the 1970s and 1980s, as a result of the leadership of Willy Brandt (197692), the SI could claim that it had the trappings of a global player. Similarly, in the immediate wake of regime change across Central and Eastern Europe post-1989 the CDI, LI and SI yielded significant ideological and programmatic influence on the newly emerging party systems. Their recent trajectory, however, especially in the European theatre where they have been displaced by the rise of the Europarties, has been less memorable. The comparison, of course, is not entirely appropriate, given the legal framework that has facilitated the latter's evolution (Day 2014; Day and Shaw 2006). But the changing fortunes of their relationship illustrate the GPIs' relative decline. Take the example of the CSPEC, the predecessor of the PES. Article 1 of the draft statute of the CSPEC read: '... [it] shall be based on the provisions of the Socialist International relating to regional cooperation among the affiliated parties', implying a degree of indebtedness to its senior partner (CSPEC 1980). From the late 1990 s to the early 2000s, however, the statutory relationship had shifted to talking in terms of 'ensuring close collaboration with the SI'. By 2012 direct reference to the SI, in the objects and aims of the PES, had been removed. The situation became even more dramatic in 2012, when a number of PES member parties (and others) broke away from the SI. They went on to form the PA, arguing that the former was in dire need of reform. Statutory recognition of the GPIs by their Europarty counterparts continues to exist in plain sight, as highlighted in Table 2.2, but it is difficult to escape the question: do Europarties believe the GPIs are fit for purpose? It is clear that both formations are part of a wider political community, yet the precise nature of that relationship has become increasingly opaque as the role and significance of the Europarties has increased since the promulgation of the 2004 Party Regulation. 
Table 2.2. Europarty statutory recognition of the Global Party Internationals

Europarty Europarty statutory recognition of its corresponding GPI

EPP 'Statutes of the European People’s Party' (2017)

Preamble: 'This association will be a member of the Christian/Centrist Democrat International (CDI), a worldwide organization of Christian Democrats and like-minded political parties and the International Democrat Union (IDU), a worldwide organization of Conservative, Christian Democrat and like-minded political parties of the centre and centre right.'

Article 6: 'Membership of the Centrist Democrat International (IDC-CDI) and/or International Democrat Union (IDU) is a positive criteria.'

\begin{tabular}{|c|c|}
\hline PES & $\begin{array}{l}\text { 'Statutes of the Socialist International' (2015) } \\
\text { Article 39: 'Composition of the Leaders' Conference includes the President of the Socialist International.' } \\
\text { Article 37.1: 'The President, in co-operation with the Vice-Presidents and with the assistance of the } \\
\text { Secretariat, shall ensure: liaison between the PES and the parties, the group in the European Parliament } \\
\text { and the Socialist International and other international initiatives such as the Progressive Alliance and the } \\
\text { Global Progressive Forum.' }\end{array}$ \\
\hline ALDE & $\begin{array}{l}\text { 'Statutes of the Alliance of Liberals and Democrats for Europe Party, European political party' (2016) } \\
\text { Article 3: [part of its purpose is to] 'develop close working relationships with and among its members, their } \\
\text { national parliamentary groups, the parliamentary Group of the ALDE Party of the European Parliament, in } \\
\text { other international fora and Liberal International'. }\end{array}$ \\
\hline EGP & $\begin{array}{l}\text { 'Statutes of the European Green Party, European Political Party (PPEU)' (2011) } \\
\text { Preamble: 'The European Green Party represents Green Parties from all over Europe, and we are part of the } \\
\text { Global Green family.' } \\
\text { Article 3.6: '[The European Green Party] acts as the European partner within the structure of the Global } \\
\text { Greens movement and subscribes to the Global Greens Charter'. }\end{array}$ \\
\hline
\end{tabular}

Despite this very real diminution, it is important not to become overly Eurocentric with regard to the prism through which an evaluation of the GPIs takes place; this remains a global story. While they may not be displaying global-level agenda-setting properties, there are still a series of tangible and intangible features/outputs that continue to underpin their sense of purpose. Chief among them is the visceral affinity that they appear to accrue. Such a way of thinking remains an essential part of the armoury of the GPIs. In addition, Congress speeches, resolutions, press releases, statutory provisions and statements of solidarity in the wake of disasters and atrocities are all aimed at galvanizing the GPI brand-though the reach and effectiveness of such words are difficult to quantify. Perhaps their most significant tangible contribution is the organization of workshops on 'party building' for member (and aspiring member) parties. The PA, for example, talks about the need to 'focus on building-up the capacity for campaigns and the organizational integrity of political parties' (Progressive Alliance n.d.). The GG take a similar approach, emphasizing capacity-building, assisting policy development, and research and campaigning (GG 2012). Such gatherings provide the opportunity to network, exchange best practice, share electioneering experiences, and hear expert commentary on new innovative communication strategies/techniques. For smaller/oppositional member parties in particular, these types of meetings often prove invaluable. 


\section{Thinking of the future}

Facing up to the 'dilemma of indifference' is not heralded as a panacea. It is, however, posited as a necessary step if GPIs wish to enhance their role and significance, and demonstrate their value-added. Indifference has a corrosive effect, which reinforces a sense of dismissiveness towards the GPIs that leaves them languishing, at best, as a peripheral concern for their member parties. Changes, however, will require national member parties to initiate a series of reforms (not least increased levels of funding) that will necessitate a shift away from a strict interpretation of the GPI as being solely an association of national political parties. The challenge associated with any reform process is dealing with the resistance to change. With national political parties at the helm, the degree of resistance to the organizational reform of the GPIs is likely to be reduced. Member parties are only going to countenance such changes if: (a) they believe that the GPI is capable of effectively taking on an increasing set of responsibilities and (b) a GPI proves itself valuable to both member parties and civil society groups. Equally important is the need to reformulate the nature of the relationship between Europarties and GPIs. The goal is to ensure that the GPI has real-world relevance from the perspective of its corresponding Europarty. Clearly there is no blueprint in this regard: each coupling must create its own bespoke arrangement. Nevertheless, it is a pathway that represents one way to enhance their relevance within and beyond the EU. Democratic legitimacy in a globalized economy is also achieved through institutionalized and substantive dialogue with political counterparts the world over. 


\section{Recommendations}

\section{Steven van Hecke}

How to broaden, deepen and diversify the ways in which European political parties are able to (re)connect with citizens is a complex challenge that will require time (short, medium and long term) and the efforts of various actors. These aims are rather ambitious, although one should not expect Europarties to deliver on what national political parties are unable to. Existing tools such as the ECI share the same objective. The recommendations presented in this section primarily address (European) political parties, but also target other levels or types of actors. They are summarized in Table 3.1.

\subsection{For European institutions}

Measures to enhance EU democracy by, for instance, holding an informal summit on 23 February 2018 on 'Institutional issues: EP composition/transnational lists, appointments, including Spitzenkandidaten' are promising (European Council 2017a, 2017b). Proposals related to these issues are aimed at strengthening electoral and participative EU democracy. Yet recent developments demonstrate that the atmosphere can change rapidly and easily. Therefore, in order to be sustainable, some changes need to be legally anchored by amending existing legislation or, eventually, treaty change.

Given the reluctance of a number of heads of state and government to support the Spitzenkandidaten system in May 2014, it is reassuring that the Spitzenkandidaten system currently seems to be part of the acquis communautaire (the body of common rights and obligations that is binding on all the EU member states) within the European Council. The European Council could strengthen its democratic legitimacy and accountability at the EU level by merging the roles of the President of the European Commission and the President of the European Council, as proposed by Commission President Juncker in his 2017 State of the Union address and foreseen in the Lisbon Treaty. This would not require a treaty change and would strengthen the link with EU citizens: as through the Spitzenkandidaten system, voters in EP elections would also have a say in the appointment of the European Council President. Furthermore, this merger would enhance the visibility of the executive at the EU level. 
The European Commission should further amend the legal framework on European political parties and foundations (European Commission 2017a). European political parties could be encouraged to become more ideologically homogeneous and strengthen their relations with a single political group in the EP. The financing rules on joint activities between European political parties and their national member parties could be softened during European elections campaigns. Furthermore, a separate campaign grant from the EU for the 2019 European elections would allow them to safeguard their operational budgets and play a more visible role. These grants could be accompanied by strict spending requirements, as is the case in several member states. Europarties could also be required to increase their transparency regarding revenues and be more open with regard to spending. In order to safeguard the democratic space at the EU level, and to avoid imbalances between larger and smaller European parties, a significant part of the funding for Europarties should be distributed in equal shares. They could be further encouraged to 'match' the European public subsidies with their own financial resources (as is the case now), as it induces them to strengthen their ties with civil society and individual EU citizens. Increasing public funding for Europarties from 85 per cent to 95 per cent of their total income could be reserved for newly established Europarties, and only for a limited period of time (one or two electoral cycles), to encourage them to continue to seek alternative funding. Using funding rules to hinder the development of Eurosceptic transnational parties is likely to backfire in terms of democratic development, and to fuel criticism of the EU's lack of democratic legitimacy.

All EU institutions - especially the EP, given its recent plans to rebuild or renovate its Brussels premises - could consider how to creatively (re)organize their working spaces to make them more accessible to citizens, balancing expectations regarding citizen participation (intensified and unmediated involvement) with more and more severe security measures (increased physical distance).

European institutions could be encouraged to regularly and critically evaluate their political and legal toolbox to maintain their link with civil society and EU citizens, and consider expanding to other citizen-oriented tools, such as public consultations, petitions and ECIs. If some instruments fail to promote a connection with citizens, EU institutions should have the courage either to reform or to repeal and replace.

EU institutions should take a straightforward position on the organization of democratic conventions in the run-up to the 2019 European elections. Such conventions can be a useful forum to reconnect with citizens, but the modalities of participation, outcome and impact remain unclear (Alemanno 2017). There is, therefore, a danger that excessively high expectations will lead to disenchantment and disengagement. This becomes even more urgent since the European Council agreed on its Leaders' Agenda, implying that the calendar of 'when to discuss what' is already more or less set until the 2019 elections, and even beyond (European Council 2017a, 2017b).

Initiatives to hold politicians in the EP and the Council of Ministers accountable, for instance VoteWatch Europe's scrutiny of voting behaviour, could be open to all citizens and not behind paywalls that restrict these tools to experts and universities. Free alternatives are available at MEPvote.eu and MEPranking.eu, but there is a need to develop these tools and expand access to them. 


\subsection{For European political parties}

Given the current institutional architecture of the EU, Europarties have less regulatory control than national parties with which to enhance democracy at the European level, even if Europarties contributed to the recent Commission proposal. They largely depend on the existing legal framework, which sets the boundaries on their room to manoeuvre. Nevertheless, Europarties play a crucial role within this setup, as they are the only entities to form bridges between politicians within the three main EU institutions (as well as with the Committee of the Regions). They also have the political and moral obligation to try to do more, and to do better, to reconnect with citizens, as this is their mission goal as defined in the party article.

To this end, European political parties and their foundations could invest more, and more creatively, in reaching out to citizens by disseminating information on EU policy issues, and not just political ideals about EU integration, in order to deepen the democratic character of institutions, and mainstream political parties should engage with dissenting voices including Eurosceptics.

Furthermore, European political parties could create horizontal platforms for exchanges between citizens and party members from different member states, regions and local communities. For example, they could be much more visible through social media, regular publications, newsletters, conferences and debates held in local languages. They could seek or build appropriate web applications and ICT tools to improve their interaction with citizens, and in the fight against the spread of 'fake news' on the EU, especially on social media platforms. Likewise, European political foundations should increase their engagement beyond the 'Brussels bubble'.

More generally, Europarties should rethink their internal decision-making bodies and procedures to help better reconnect with EU citizens, for example by increasing individual membership and non-member affiliation. Individual members would need to be granted rights, such as the right to participate in policymaking and the selection of leaders to represent them at party congresses and other relevant party bodies, where they have the right to vote.

Party associations (youth, women, seniors, etc.) should be included in decisionmaking processes in order to diversify party memberships. Efforts should be made to ensure that the preferences of underrepresented groups are taken into account, and that such groups are represented within the party bodies.

The relationship between European political parties and their political groups in the EP should be strengthened, and coordination among ministers in the Council and in the European Council summitry should be enhanced. While this advantages only parties that are adequately represented, some political families will need to improve their electoral performance in order to be better represented not only in the EP, but also in the Council of Ministers and the European Council.

Furthermore, European political parties have the responsibility to select their respective Spitzenkandidat in a timely and democratic manner. This does not necessarily require non-members to participate (i.e. in open primaries), but candidates should be selected taking into account the fact that broader support will be needed within the EP in order for her (or him) to become the next President of the European Commission. If, like in 2014, the European political parties and their 
respective groups in the EP propose a united candidate for the presidency of the Commission, the member states, through the European Council, will be forced to accept their candidate.

Finally, European political parties should engage more with, and contribute to strengthening and developing, international networks such as GPIs, which are often undervalued political spaces that could provide an essential platform for mutual learning and capacity-building. The relevance of GPIs, however, depends on their added value in multilateral forums and enhanced links with civil society, as well as introducing forms of individual membership and greater coordination, both internally and with regard to global counterparts.

\subsection{For national political parties}

National political parties can facilitate increased space, and enhanced roles, for their Europarty at both the national and European levels. For instance, through their member state governments, they could promote the 'parliamentarization' of the EU by allowing only elected MEPs to be eligible for the post of commissioners, a model that is applied in many parliamentary systems. Together with the introduction of transnational lists, this approach would raise the stakes of EP elections, which could increase citizens' interest and their perception that their voice counts. It would also increase the Commission's legitimacy and oblige national parties to more regularly take EU affairs into account and to connect more with their MEPs and their European political party. (If the member states' governments are not favourable of that idea, the EP should make participation in EP elections conditional on the hearings of the candidate-commissioners. The same is true for the Spitzenkandidaten to become President of the European Commission through a vote of the EP.)

Simultaneous European and national elections should be avoided in order to prevent EU issues from being overshadowed by national concerns.

National elections should no longer take place in isolation from EU affairs; key issues in European elections could also be addressed in the context of national campaigns. European political family logos should be displayed alongside national party logos on ballots in order to strengthen the perceived links between them. National parties could also formally endorse their Europarty's manifesto and political programmes, and debate these issues to increase awareness between elections.

\subsection{For European civil society}

Traditional civil society players could do more to consistently and publicly engage with European political parties, and vice versa. National-level practices such as civil society organizations that present their memoranda (grievances, expectations and so on) to political parties during electoral campaigns and in the run-up to the installation of a new government, could be more extensively applied at the EU level (see e.g. platforms such as On Our Watch).

To increase their relevance outside the Brussels bubble, non-traditional civil society players, such as social media platforms, could engage more (and more directly) with citizens in member states, for example by convening hackathons and online citizens' 
conventions. See, for instance, the four families of civic tech that want to renew EU democracy (Décrypter la communication européenne 2017).

\subsection{For EU citizens}

Citizens can engage within European political parties and have the political right to inform themselves and make their choice heard. In other words, if they want the EU to become more democratic and legitimate, citizens have to take part in the debate and vote. School curricula should include more on how the EU works, and how this relates to national politics and their daily lives, in order to improve EU citizenship sustainably and boost youth voter turnout. It will also weaken the influence of fake news and decrease the number of citizens who take negative stands on the EU based on false information.

These recommendations are targeted at enabling and promoting the bottom-up engagement of EU citizens. Schattschneider (1942[2004]: 1) has posited that 'modern democracy is unthinkable save in terms of parties'. This is certainly also true for the current EU. Therefore, the role of European political parties is crucial. But EU democracy, like any democracy, is equally unthinkable without the participation of citizens. 
Table 3.1. Overview of short-, medium- and long-term recommendations

\begin{tabular}{|c|c|c|c|}
\hline Actor(s) & Short term & Medium term & Long term \\
\hline $\begin{array}{l}\text { European } \\
\text { Union } \\
\text { citizens }\end{array}$ & \multicolumn{3}{|l|}{ INFORM $>$ ENGAGE $->$ VOTE } \\
\hline $\begin{array}{l}\text { National } \\
\text { parties }\end{array}$ & $\begin{array}{l}\text { Debate EU issues in } \\
\text { national elections } \\
\text { Indicate the Europarty } \\
\text { symbol during national } \\
\text { elections } \\
\text { Endorse the Europarty's } \\
\text { manifesto and political } \\
\text { programme } \\
\text { Constitute a citizens' forum } \\
\text { on EU issues } \\
\text { Focus on EU issues between } \\
\text { election seasons }\end{array}$ & $\begin{array}{l}\text { Non-concurrent elections (national/ } \\
\text { EU) } \\
\text { Transfer of power to Europarties (e.g. } \\
\text { candidate selection) }\end{array}$ & $\begin{array}{l}\text { National political parties should } \\
\text { not intervene in EU elections } \\
\text { (Europarty symbol on the ballot } \\
\text { paper) }\end{array}$ \\
\hline Europarties & $\begin{array}{l}\text { Membership for individual } \\
\text { citizens and possibility of } \\
\text { tiered system of affiliation } \\
\text { short of membership } \\
\text { Develop permanent forums } \\
\text { for citizens, beyond the } \\
\text { Brussels bubble } \\
\text { Ensure that party } \\
\text { foundations also improve } \\
\text { outreach beyond Brussels } \\
\text { Greater presence on social } \\
\text { media } \\
\text { Engage with civil society as } \\
\text { a whole } \\
\text { Engage with non-EU and } \\
\text { global arenas (e.g. through } \\
\text { GPIs) }\end{array}$ & $\begin{array}{l}\text { Rethink internal decision-making } \\
\text { structures (i.e. greater role for } \\
\text { individual members, majority voting, } \\
\text { representation of party associations) } \\
\text { Primaries for Spitzenkandidaten } \\
\text { Increase own funding (membership } \\
\text { fees, etc.) } \\
\text { Openness and transparency of } \\
\text { revenues and spending patterns } \\
\text { Strengthen links with groups in the EP } \\
\text { Improve ideological homogeneity } \\
\text { Strengthen European Council } \\
\text { summitry coordination }\end{array}$ & $\begin{array}{l}\text { Spitzenkandidaten (US-style } \\
\text { system) }\end{array}$ \\
\hline $\begin{array}{l}\text { European civil } \\
\text { society }\end{array}$ & $\begin{array}{l}\text { Address memoranda on key } \\
\text { issues directly to EU parties, } \\
\text { and not only during } \\
\text { campaigns }\end{array}$ & $\begin{array}{l}\text { Support citizens' understanding of EU } \\
\text { policymaking }\end{array}$ & \\
\hline $\begin{array}{l}\text { European } \\
\text { institutions }\end{array}$ & $\begin{array}{l}\text { Reconsider the balance } \\
\text { between (demands for) } \\
\text { unmediated citizen } \\
\text { participation and security } \\
\text { concerns } \\
\text { Greater clarity on the impact } \\
\text { and outcome of } 2018 \\
\text { 'democratic conventions' }\end{array}$ & $\begin{array}{l}\text { Redistribute some funding to } \\
\text { Europarties in equal shares in order to } \\
\text { redress imbalances between larger } \\
\text { and smaller parties } \\
\text { Restriction of } 95 \text { per cent funding } \\
\text { regime for newly established parties } \\
\text { and for a limited time period } \\
\text { Rules on joint activities between } \\
\text { Europarties and their national } \\
\text { member parties } \\
\text { Introduce separate campaign grant } \\
\text { with strict requirements }\end{array}$ & $\begin{array}{l}\text { Reconsider, reform and improve } \\
\text { their legal and political toolbox to } \\
\text { ensure links with EU citizens } \\
\text { Consider merging the roles of } \\
\text { President of the European } \\
\text { Commission and President of the } \\
\text { European Council }\end{array}$ \\
\hline
\end{tabular}




\section{Annex. Proposals on transnational lists for the European Parliament}

\section{Wouter Wolfs and Steven van Hecke}

The long-term goal of strengthening EU democracy through increased citizen participation can be achieved through dual direct elections - of the legislature (at least one of its chambers, here the EP) and the executive (which is, in the case of the EU, the President of the European Commission). This set-up is modelled after the United States, where the executive and legislative branches gain their legitimacy through separate elections. In order to avoid gridlock between these two branches, as is often the case in the USA, strong parties are needed that create bridges between 'the parliament' and 'the government'. Logically, in the case of the EU, this role would be assigned to the Europarties. This model, put forward by Luc van den Brande (2017), especially the direct election of the Commission President, currently has little political support.

This Annex presents a number of technical proposals regarding the establishment of transnational lists for EP elections. However, all solutions involving transnational lists are suboptimal, for empirical, practical and theoretical reasons. First, electoral lists within constituencies that coincide with the entire territory of the polity generally do not exist for the election of the legislature in national elections (either in federal systems like the USA or Germany, or in assemblies of large states like Russia). The entire polity only directly elects the executive (e.g. France). This is because such systems need lists with regional quotas in order to guarantee democratic representation, which is difficult in a context of 28 member states. Second, introducing a transnational list could compound the problem of asymmetries among member states related to organizing the election of MEPs. For instance, candidates of a single pan-European list may have to be 18 years old if they are Danish nationals, but 25 if they are Italian nationals. Although the EP adopted a report to increase the uniformity of European elections, it is not clear how many of the report's proposals will be implemented before the 2019 elections (European Parliament 2014, 2018a, 2018b). Third, further 'parliamentarization' of the EU polity, as found in many member states, should be avoided. The shift from ad hoc and variable majorities to a fixed majority/opposition system often leads to 'executive dominance': eventually the executive controls the parliament. It would weaken the legislature, preventing an 
evaluation of legislation on its own merits. Holding non-simultaneous elections of the executive and legislative branches like in France helps retain the prominence of the legislature.

In other words, transnational lists should be used for EP elections only if the European Commission President is not directly elected. Transnational lists do not represent a short-term solution; they can serve as an intermediate step towards achieving a more democratic union.

The introduction of transnational electoral lists has been debated for years, but so far no majority has been formulated in the EP or Council of Ministers. The proposal of MEP Andrew Duff in the previous term of the EP (2009-14) on the provisions of elections to the EP included the idea to create a pan-European constituency to elect 25 MEPs on transnational lists (European Parliament 2011). The proposal proved to be too controversial. Although reservations remain in several member states and political groups, the idea of a pan-European electoral district is gaining momentum. During his State of the Union address in September 2017, President Juncker expressed his support for the introduction of transnational lists (European Commission 2017a). Two weeks later, French President Macron in his Sorbonne speech suggested that the 73 seats of the British MEPs should be used to create a panEuropean district for the 2019 European elections, and proposed that half of the EP should be elected through transnational lists by the 2024 elections (Macron 2017).

Although the idea of a pan-European district is gaining traction, many questions remain. Supporters of transnational lists agree on the basic principles: only a limited number of seats would be elected through transnational lists in a proportional representation system, and one voter would get two votes (one for the pan-European electoral district, and one for the electoral district in her/his member state) for the remaining EP seats. However, the specific technicalities and implementation of transnational lists are less clear. Below, three possible models are presented, and advantages and challenges discussed. The models all consider a situation in which a fixed number of seats - for example 50 - is allocated using a pan-European district.

Implementing transnational lists would involve exploring a number of questions related to the modalities and mechanisms that will be adopted:

1. Should an open, semi-open or closed party list system be chosen? In an open-list system, voters can influence the order of the candidates on that list, usually through preferential voting. In a closed-list system, voters can only vote for the entire party list without changing the order of candidates. A closed-list system increases party control, since they determine the order of the candidates. A semi-open list gives voters the possibility to cast either party list or preferential votes.

2. If an open-list system is adopted, how many preference votes should a voter receive? The number can range from one to the total number of seats to be distributed. An additional question is whether a voter can express her/his preference votes within a single list or across several party lists (this is known as 'panachage'). The more preference votes a voter can cast, the greater the chances that (s)he will vote for a candidate that is not from her/his member 
state. Since voters are not (yet) socialized into voting for non-nationals, if they have only one preference vote to cast, they are likely to vote for a candidate from their country.

3. Should member state quotas be applied to the party lists? Parties can be forced to present a geographically balanced list of candidates in order to ensure that a pan-European electoral district does not produce a representation that favours certain (larger) member states.

4. If geographical quotas are adopted, the candidate characteristic that must be considered as a criterion must be determined: should an electoral list be balanced in terms of candidate nationality or country of residence? For example, would a person with German nationality who is living in France be counted towards the quota of France or Germany? Current provisions allow EU citizens to stand as candidates for the European elections in the EU member state in which they reside: a German person elected in France counts as a 'French' seat in the EP.

5. Will double candidacy be allowed? Can a person stand for election on both a transnational and national list? What happens if a candidate is elected on both lists?

6. Which divisor will be used to calculate the distribution of seats among the various Europarties? Most member states use the D'Hondt method, which slightly favours larger parties.

7. Should an electoral threshold be introduced for a party to be allocated parliamentary seats? The higher the number of seats that are allocated in a panEuropean district, the more likely smaller Europarties are to be able to obtain sufficient votes to get a seat.

\section{Proposal 1: Transnational lists as a 29th (pan-European) electoral district}

\section{Proposal 1: summary}

STEP 1: The seats are allocated among the various European political parties based on the number of total votes for each Europarty, following a specific apportionment method.

STEP 2: The seats of each European political party are assigned to the candidates on the list who have received the most preference votes.

STEP 3: The seats in the 28 member states are distributed separately from the pan-European district.

In this system, the seats that are allocated in a pan-European district are distributed separately from the seat allocation in the various national districts. In other words, the EU-wide seats have no impact on the seat distribution in the member states; the elected candidates on the transnational lists can be from any member state. The pan- 
European district therefore functions as an additional electoral district alongside the 28 national electoral districts.

The main feature of this model is that the number of seats for each member state will vary from election to election. It is impossible to anticipate how many MEPs will come from a particular member state after the European elections. The most significant challenge is that this could lead to an 'overrepresentation' of MEPs from member states with larger populations, particularly in the first elections after transnational lists are introduced, assuming that it will take some time for the European 'demos' to grow. If voters are not yet used to voting for candidates from another member state and the electoral campaigns are not sufficiently Europeanized, there is a risk that voters will mainly vote for candidates from their own member state, regardless of which list they are on. This will result in more preference votes for candidates from larger member states, making it difficult for candidates from smaller states to obtain a seat in the EP.

This challenge could be addressed by introducing closed lists in combination with geographical quotas. In closed lists, the order of the seat distribution among candidates is only determined by candidates' position on the list. The adoption of geographical quotas - comparable to gender quotas - ensures that the electoral lists include candidates from different member states, which would result in a geographically balanced representation for each Europarty. How can such quotas be devised in practice? Member states could be divided into four groups based on their population, and the European political parties could be required to select an equal number of candidates from each group on their electoral lists, or each of the top four candidates on the list could be required to come from one of the four groups. Adopting quotas for groups of member states rather than for individual member states gives Europarties a degree of flexibility in their candidate selection. This is particularly important for those that do not have members in each member state.

A closed-list system with geographical quotas, however, entails two main disadvantages. First, voters cannot change the order of the list or vote only for particular candidates. They can vote only for parties, not for candidates. Second, a closed-list system may give too much control over candidate-selection to the central Europarty headquarters, which could diminish the independence and discretion of individual MEPs (as is the case in several member states).

A broader challenge associated with this model is the limited political feasibility of its implementation. As past examples have shown, the composition of the EP is a sensitive issue. The number of EP seats for each member state has been the subject of major controversy in the past. Since this model does not determine how many seats each member state would have in the EP, a Europarty might jeopardize its chances of finding sufficient support. The two following models anticipate this challenge by keeping the number of seats for each member state fixed. 


\section{Proposal 2: Transnational lists with fixed seat distribution for member states (priority transnational lists)}

\section{Proposal 2: summary}

STEP 1: The seats are allocated among the various European political parties based on the number of total votes for each Europarty following a specific apportionment method.

STEP 2: The seats of each European political party are assigned to the candidates on the list who have received the most preference votes.

STEP 3: Each member state loses one seat for their national distribution of seats for each elected panEuropean candidate from that member state.

In this model, the distribution of seats in the EU-wide district is coupled with the distribution of seats in the member states to ensure that the number of seats for each member state does not change. Before the elections, the exact number of seats for each member state will be determined. Nevertheless, a number of seats are distributed in an EU-wide district, and this distribution has priority over the distribution of seats in the member states.

For example, Germany has a fixed number of 96 seats in the EP. In the Europeanwide district six candidates from Germany are elected from the transnational lists (for all Europarties combined); the total number of German seats is reduced by this number. The remaining 90 seats are allocated in the German electoral district.

The main advantage of this system is that the number of seats for each member state remains constant. Since the transnational seat distribution has priority over the national seat distribution, this should provide an incentive for Europarties to present strong candidates on the transnational lists.

The main challenge of this model is that it requires all member states to introduce nation-wide districts for the European elections or, if the seat distribution does not take place at the national level but in several regional districts, to have an internal mechanism to determine which regional electoral districts would lose seats. Furthermore, this model is only politically viable as long as the number of transnational seats that are distributed remains low. 


\section{Proposal 3: Transnational lists with fixed seat distribution for member states (priority national lists)}

\section{Proposal 3: summary}

STEP 1: The seats that are reserved for each member state go to the candidates of that member state who have received the most preference votes. For example, if the quota of seats for Germany is five, the five German candidates with the most preference votes-of all Europarties-are allocated a seat.

(Note: there is no first distribution of seats among parties; seats are directly allocated to individual candidates).

STEP 2: The seats in the 28 member states are distributed separately from the pan-European district.

In the third model, it is decided before the elections how many seats of the panEuropean district are reserved for each member state. The number of transnational seats depends on each member state's population. Depending on whether the United Kingdom leaves the EU, there are several scenarios involving the seat quotas for each member.

\section{UK-included scenario}

4: (>50 million) Germany, France, UK and Italy

3: (>35 million) Spain and Poland

2: (>10 million) Romania, the Netherlands, Belgium, Greece, Czech Republic and Portugal

1: (<10 million) Hungary, Sweden, Austria, Bulgaria, Denmark, Finland, Slovakia, Ireland, Croatia, Lithuania, Slovenia, Latvia, Estonia, Cyprus, Luxembourg and Malta

$=16+6+12+16=50$

\section{Post-Brexit scenario with 50 seats}

6: (>75 million) Germany

5: (>50 million) France and Italy

3: (>35 million) Spain and Poland

2: (>10 million) Romania, the Netherlands, Belgium, Greece, Czech Republic and Portugal

1: (<10 million) Hungary, Sweden, Austria, Bulgaria, Denmark, Finland, Slovakia, Ireland, Croatia, Lithuania, Slovenia, Latvia, Estonia, Cyprus, Luxembourg and Malta

$=6+10+6+12+16=50$ 


\section{Post-Brexit scenario with 73 seats}

5: ( $>50$ million) Germany, France and Italy

4: (>35 million) Spain and Poland

3: (>10 million) Romania, the Netherlands, Belgium, Greece, Czech Republic and Portugal

2: (<10 million) Hungary, Sweden, Austria, Bulgaria, Denmark, Finland, Slovakia, Ireland, Croatia, Lithuania, Slovenia, Latvia, Estonia, Cyprus,

Luxembourg and Malta

$=15+8+18+32=73$

It is not possible to allocate more (or fewer) seats to candidates from the same member state. These quotas are also calculated for all European political parties combined. For example, in the post-Brexit scenario, no more than five candidates from Germany are allocated a seat. These five German seats could be obtained by a single Europarty or by five different ones (each with one German candidate obtaining a seat).

European political parties cannot have more (or fewer) candidates from a member state on their transnational lists than there are seats reserved for that member state. This will provide a level playing field among parties by preventing them from limiting the number of transnational candidates from one member state to maximize their votes. Furthermore, it will also prevent many candidates from being overlooked in the allocation of seats.

In this model, voters vote for candidates rather than for parties. This could lead to interesting debates between candidates from the various Europarties that all compete for the seats of the same member state. The 'transnational' dimension of this model is more limited than in the previous models, although citizens can still vote for candidates from other member states. 
Achury, S. et al, 'The consequences of membership incentives: do greater political benefits attract different kinds of members?', Party Politics, 31 January 2018, <https://doi.org/10.1177/1354068818754603>

Alemanno, A., ' 5 big ideas to reboot democracy in the EU', World Economic Forum, 16 October 2017, <https:/www.weforum.org/agenda/2017/10/5-bigideas-to-reboot-democracy-in-the-eu>, accessed 27 March 2018

Armingeon, K. and Guthmann, K., 'Democracy in crisis? The declining support for national democracy in European countries, 2007-2011', European Journal of Political Research, 53/3 (2014), pp. 423-42, <https://doi.org/ 10.1111/1475-6765.12046>

Bardi, L., 'Parties and party systems in the European Union: national and supranational dimensions', in K. R. Luther and F. Müller-Rommel (eds), Political Parties in the New Europe: Political and Analytical Challenges (Oxford: Oxford University Press, 2002)

—, 'EU Enlargement, European Parliament elections and transnational trends in European Parties', European View, 2/1 (2006), pp. 13-19

Bardi, L. et al., How to Create a Transnational Party System (Brussels: European Parliament, 2010), <https://www.eui.eu/Projects/EUDO/Documents/ EUDOReport2web.pdf>, accessed 28 November 2018

Beyme, K. von, Political Parties in Western Democracies (Aldershot: Gower, 1985)

van Biezen, I., 'Political parties as public utilities', Party Politics, 10/6 (2004), pp. 701-22, <https://doi.org/10.1177/1354068804046914>

van Biezen, I., Mair, P. and Poguntke, T., 'Going, going, ... gone? The decline of party membership in contemporary Europe', European Journal of Political Research, 51/1 (2012), pp. 24-56, <https://doi.org/10.1111/j. 1475-6765.2011.01995.x> 
Brack, N., 'The roles of Eurosceptic Members of the European Parliament and their implications for the EU', International Political Science Review, 36/3 (2015), pp. 337-50, <https://doi.org/10.1177/0192512115571590>

—, Opposing Europe in the European Parliament: Rebels and Radicals in the Chamber (London: Palgrave, 2018), <https://doi.org/10.1057/978-1-137-60201-5>

Brack, N. and Startin, N., 'Euroscepticism: from the margins to the mainstream', International Political Science Review, 36/3 (2015), pp. 239-49, <https:// doi.org/10.1177/0192512115577231>

van den Brande, L., 'Reaching Out to EU Citizens: A New Opportunity - About us, with us, for us', European Commission, 2017, <https://ec.europa.eu/ commission/sites/beta-political/files/reaching-out-to-citizens-report_en.pdf>, accessed 27 March 2018

Confederation of Socialist Parties of the European Community (CSPEC), Draft Statute of the CSPEC, 14 February 1980, PS/CE/6/80

W. Cross and R. S. Katz (eds), The Challenges of Intra-Party Democracy (Oxford: Oxford University Press, 2013), <https://doi.org/10.1093/acprof:oso/ 9780199661879.001.0001>

Cross, W. and Pilet, J.-B., The Politics of Party Leadership (Oxford: Oxford University Press, 2016)

Dalton, R. J. and Wattenberg, M. P., Parties Without Partisans: Political Change in Advanced Industrial Democracies (Oxford, New York: Oxford University Press, 2000)

Day, S., 'Between "containment" and "transnationalization": where next for the Euro-parties?', Acta Politika, 49/1 (2014), pp. 5-29, <https://doi.org/10.1057/ ap.2013.23>

Day, S. and Shaw, J., 'The evolution of Europe's transnational political parties in the era of European citizenship', in T. A. Börzel and R. A. Cichowski (eds), The State of the European Union, 6: Law, Politics, and Society (Oxford: Oxford University Press, 2003), <https://doi.org/10.1093/019925740X.003.0007>

—, 'Political parties in the European Union: towards a European party statute?' in K. D. Ewing, S. Issacharoff (eds), Party Funding and Campaign Financing in International Perspective (Oxford: Hart Publishing, 2006)

Décrypter la communication européenne, 'Cartographie des civic tech européennes' [Cartography of the European civic tech], 10 May 2017, <http:// www.lacomeuropeenne.fr/2017/05/10/cartographie-des-civic-techeuropeennes>, accessed 29 March 2018 
Delwit, P., Külahci, E. and Van de Walle, C., The Europarties: Organization and Influence (Brussels: Editions de l'Université de Bruxelles, 2004)

Deschouwer, K., 'Political parties as multi-level organizations', in R. S. Katz and W. Crotty (eds), Handbook of Party Politics (London: Sage, 2006), <https://doi.org/ 10.4135/9781848608047.n25>

Duverger, M., Les Partis Politiques [Political parties] (Paris: Colin, 1951)

European Commission, 'President Jean-Claude Juncker's State of the Union Address 2017’, Brussels, 13 September 2017a, <http://europa.eu/rapid/pressrelease_SPEECH-17-3165_en.htm>, accessed 27 March 2018

—, Two Visions, One Direction: Plans for the Future of Europe, 29 September 2017b, $<$ https://ec.europa.eu/epsc/publications/other-publications/two-visions-onedirection---plans-for-the-future-of-europe_en>, accessed 27 March 2017

—, 'Proposal for a Regulation on the Statute and Funding of European Political Parties and European Political Foundations', 2017c, <https://ec.europa.eu/ commission/publications/proposal-regulation-statute-and-funding-europeanpolitical-parties-and-european-political-foundations_en>, accessed 27 March 2018

—, 'European Citizens' Initiative', [n.d.], <http://ec.europa.eu/citizens-initiative/ public/welcome>, accessed 28 March 2018

European Council, 'Documents by President Donald Tusk for the members of the European Council: invitation letter, Leaders' Agenda and Bratislava implementation report', 2017a, <http:/www.consilium.europa.eu/en/press/ press-releases/2017/10/17/tusk-invitation-letter-euco/>, accessed 27 March 2018

—, 'Leaders' Agenda: Building our Future Together', 2017b, <http:// www.consilium.europa.eu/en/policies/tallinn-leaders-agenda/>, accessed 27 March 2018

European Parliament, 'Report on the constitutional status of the European political parties' [Tsatsos report], 30 October 1996, <http://www.europarl.europa.eu/ sides/getDoc.do?pubRef=-//EP// TEXT+REPORT+A4-1996-0342+0+DOC+XML+V0// EN\#Contentd319918e339>, accessed 29 October 2018

—, 'Report on a Proposal for a Modification of the Act Concerning the Election of the Members of the European Parliament by Direct Universal Suffrage of 20 September 1976 (2009/2134(INI))', 2011

—, 'European Elections: National Rules', 10 April 2014, <http:// www.europarl.europa.eu/RegData/bibliotheque/briefing/2014/140762/ LDM_BRI(2014)140762_REV3_EN.pdf>, accessed 27 March 2018 
—, Directorate for Political Structures Financing and Resources, 'Grants from the European Parliament to political parties at European level per party and per year', October 2017,<http://www.europarl.europa.eu/pdf/grants/ Grant_amounts_parties_10_2017.pdf>, accessed 28 November 2018

—, 'The European Parliament: Electoral Procedures', 2018a, <http:// www.europarl.europa.eu/ftu/pdf/en/FTU_1.3.4.pdf>, accessed 27 March 2018

—, 'Reform of the Electoral Law of the EU', 2018b, <http:// www.europarl.europa.eu/legislative-train/theme-union-of-democratic-change/ file-reform-of-the-electoral-law-of-the-eu>, accessed 27 March 2018

—, Europa portal, [n.d.], <http://www.europarl.europa.eu/portal/en>, accessed 28 March 2018

European Parliament and Council, 'Regulation (EC) No. 2004/2003 of the European Parliament and the Council of 4 November 2003 on the regulations governing political parties at European level and the rules regarding their funding', Official Journal of the European Union, L297/1-4, 15 November 2003

—, 'Regulation (EU, EURATOM) No. 1141/2014 of the European Parliament and of the Council of 22 October 2014 on the statute and funding of European political parties and European political foundations', Official Journal of the European Union, L 317/1, 4 November 2014

Franklin, M. and Hobolt, S., 'The legacy of lethargy: how elections to the European Parliament depress turnout', Electoral Studies, 30/1 (2011), pp. 67-76, <https:// doi.org/10.1016/j.electstud.2010.09.019>

Gagatek, W., European Political Parties as Campaign Organizations: Toward a Greater Politicisation of the European Parliament Elections (Brussels: Centre for European Studies, 2009)

—, 'Explaining legislative conflict over the adoption of political financing law in the European Union', in I. van Biezen and H.-M. ten Napel (eds), Regulating Political Parties. European Democracies in Comparative Perspective (Leiden: Leiden University Press, 2014)

Gagatek, W. and van Hecke, S., 'The development of European political foundations and their role in strengthening Europarties', Acta Politica, 49/1 (2014), pp. 86104, <https://doi.org/10.1057/ap.2013.27>

Gauja, A., The Politics of Party Policy: From Members to Legislators (Basingstoke: Palgrave Macmillan, 2013), <https://doi.org/10.1057/9781137318428>

—, Party Reform: The Causes, Challenges, and Consequences of Organizational Change (Oxford: Oxford University Press, 2017) 
Global Greens, 'Future functioning and structure of the Global Greens', 23 May 2012, <https://www.globalgreens.org/dakar2012/resolutions/global-greensfuture-functioning-and-structure>, accessed 29 October 2018

Hällhag, R., 'Political party internationals as guardians of democracy-their untapped potential', Internationale Politik und Gesellschaft, 1 (2008), pp. 10015

Hanley, D., 'The European People's Party: towards a new party form?', in D. Hanley (ed.), Christian Democracy in Europe: A Comparative Perspective (London: Pinter Publishers, 1994)

-, Beyond the Nation State: Parties in the Era of European Integration (Basingstoke: Palgrave Macmillan, 2008)

van Haute, E., Paulis, E. and Sierens, V., 'Assessing party membership figures: the MAPP dataset', European Political Science (2017)

van Hecke, S., 'On the road towards transnational parties in Europe: why and how the European People's Party was founded', European View, 2/1 (2006), pp. 153-60

—, 'Do transnational party federations matter? (... and why should we care?)', Journal of Contemporary European Research, 6/3 (2010), pp. 395-411

van Hecke, S., Wolfs, W. and de Groof, V., '25 years of Spitzenkandidaten: What does the future hold?', Wilfred Martens Centre for European Studies Policy Brief, November 2018, <https://martenscentre.eu/publications/25-yearsspitzenkandidaten-what-does-future-hold>, accessed 19 November 2018

Hertner, I., 'Are European election campaigns Europeanized? The case of the party of European socialists in 2009', Government and Opposition, 46/3 (2011), pp. 321-44, <https://doi.org/10.1111/j.1477-7053.2011.01341.x>

-, Centre-left Parties and the European Union: Power, Democracy, and Accountability (Manchester: Manchester University Press, forthcoming)

Hix, S., The Political System of the European Union, 2nd edn (Basingstoke: Palgrave Macmillan, 2005)

-, What's Wrong with the European Union and How to Fix it (Cambridge: Polity Press, 2008)

Hix, S. and Bartolini, S., Politics: The Right or the Wrong Sort of Medicine for the EU? (Paris: Notre Europe, 2008)

Hix, S. and Lord, C., Political Parties in the European Union (Basingstoke: Macmillan, 1997) 
Hix, S., Noury, A. G. and Roland, G., Democratic Politics in the European Parliament (Cambridge: Cambridge University Press, 2007), <https://doi.org/10.1017/ CBO9780511491955>

International Democrat Union (IDU), 'The Founding Meeting of the Union and Declaration of Principles', London, 24 June 1983, <https://www.idu.org/about/ history/>, accessed 29 October 2018

International Institute for Democracy and Electoral Assistance (International IDEA), The Global State of Democracy: Exploring Democracy's Resilience (Stockholm: International IDEA, 2017), <http://www.idea.int/gsod>, accessed 29 October 2018

Johansson, K. M., 'Tracing the employment title in the Amsterdam Treaty. Uncovering transnational coalitions', Journal of European Public Policy, 6/1 (1999), pp. 85-101, <https://doi.org/10.1080/135017699343810>

-, 'Party elites in multilevel Europe: The Christian Democrats and the Single European Act', Party Politics, 8/4 (2002a), pp. 423-39, <https://doi.org/ $10.1177 / 1354068802008004004>$

-, 'Another road to Maastricht: The Christian Democrat Coalition and the quest for European Union', Journal of Common Market Studies, 40/5 (2002b), pp. 895-919

—, 'The emergence of political parties at European level: integration unaccomplished', in L. Pehrson, L. Oxelheim and S. Gustavvson (eds), How Unified Is the European Union? European Integration Between Visions and Popular Legitimacy (Heidelberg: Springer, 2009), <https://doi.org/ 10.1007/978-3-540-95855-0>

-, 'Europarty influence and its limits: the case of the European People's Party and the Amsterdam Treaty', Journal of European Integration, 38/1 (2016), pp. 7994, <https://doi.org/10.1080/07036337.2015.1088012>

-, 'The role of Europarties in EU treaty reform: theory and practice', Acta Politica, 52/3 (2017), pp. 286-305, <https://doi.org/10.1057/s41269-016-0024-y>

Johansson, K. M. and Raunio, T., 'Regulating Europarties: cross-party coalitions capitalising on incomplete contracts', Party Politics, 11/5 (2005), pp. 515-34, $<$ https://doi.org/10.1177/1354068805054978>

Katz, R. S. and Mair, P., 'Changing models of party organization and party democracy: the emergence of the cartel party', Party Politics, 1/1 (1995), pp. 528, <https://doi.org/10.1177/1354068895001001001>

Klüver, H. and Rodon, T., 'Explaining policy position choice of Europarties: the effect of legislative resources', British Journal of Political Science, 43/3 (2012), pp. 629-50, <https://doi.org/10.1017/S0007123412000543> 
Kosiara-Pedersen, K., Scarrow, S. and van Haute, E. 'Rules of engagement? Party membership costs, new forms of party affiliation, and partisan participation', in S. Scarrow, P. D. Webb and T. Pguntke (eds), Organizing Political Parties. Representation, Participation, and Power (Oxford: Oxford University Press, 2017)

Kreppel, A., The European Parliament and Supranational Party System: A Study in Institutional Development (Cambridge: Cambridge University Press, 2001)

Lightfoot, S., Europeanizing Social Democracy? The Rise of the Party of European Socialists (London: Routledge, 2005)

-, 'National political parties and European governance: the consequences of "missing in action"', West European Politics, 30/5 (2007), pp. 945-60, <https:// doi.org/10.1080/01402380701617365>

Ladrech, R., 'The European Union and political parties', in R. S. Katz and W. Crotty (eds), Handbook of Party Politics (London: Sage, 2006)

Luther, K. R. and Müller-Rommel, F., 'Parties and party research in the new Europe', in K. R. Luther and F. Müller-Rommel (eds), Political Parties in the New Europe: Political and Analytical Challenges (Oxford: Oxford University Press, 2002)

Macron, E., 'Initiative for Europe: a sovereign, united, democratic Europe', 26 September 2017, <http://www.elysee.fr/assets/Initiative-for-Europe-a-sovereignunited-democratic-Europe-Emmanuel-Macron.pdf>, accessed 29 October 2018

Mair, P., 'Political opposition and the European Union', Government and Opposition, 42/1 (2007), pp. 1-17, <https://doi.org/10.1111/j.1477-7053.2007.00209.x>

Mair P. and Thomassen J., 'Political representation and government in the European Union', Journal of European Public Policy, 17/1 (2010), pp. 20-35, <https:// doi.org/10.1080/13501760903465132>

Mühlböck, M., 'Linking Council and European Parliament? Voting unity of national parties in bicameral EU decision-making', Journal of European Public Policy, 20/4 (2013), pp. 571-88, <https://doi.org/10.1080/13501763.2012.718889>

Neven, M., 'Improving the EU's political identity and democracy: supporting European political parties to reunite with citizens', International IDEA, 26 July 2017, <https://www.idea.int/news-media/news/improving-eu-political-identitydemocracy-supporting-european-political-parties>, accessed 27 March 2018

Niedermayer, O., Europäische Parteien: Zur Grenzüberschreitenden Inter-aktion politischer Parteien im Rahmen des EG [European parties: on the cross-border interaction of political parties in the framework of the European Community] (Frankfurt: Campus Verlag, 1983) 
Otjes, S. and van der Veer, H., 'The eurozone crisis and the European Parliament's changing lines of conflict', European Union Politics, 17/2 (2016), pp. 242-61, <https://doi.org/10.1177/1465116515622567>

Panebianco, A., Political Parties: Organization and Power (Cambridge: Cambridge University Press, 1988)

Progressive Alliance, 'Guiding Principles', [n.d.], <http://progressive-alliance.info/ network/guiding-principles/>, accessed 29 March 2018

Put, G. et al., 'The choice of Spitzenkandidaten: a comparative analysis of the Europarties' selection procedures', Politics and Governance, 4/1 (2016), pp. 922, <https://doi.org/10.17645/pag.v4i1.469>

G. Rahat and R. Hazan (eds), Democracy within Parties: Candidate Selection Methods and Their Political Consequences (Oxford: Oxford University Press, 2011)

Raunio, T., 'Political parties in the European Union', in K. E. Jorgensen, M. Pollack and B. J. Rosamond (eds), The Sage Handbook of European Union Politics (London: Sage, 2006), <https://doi.org/10.4135/9781848607903.n13>

Reif, K., 'National electoral cycles and European elections 1979 and 1984', Electoral Studies, 3/3 (1984), pp. 244-55, <https://doi.org/ $10.1016 / 0261-3794(84) 90005-2>$

Reif, K. and Schmitt, H., 'Nine second-order national elections: a conceptual framework for the analysis of European elections results', European Journal of Political Research, 8/1 (1980), pp. 3-44, <https://doi.org/10.1111/j. 1475-6765.1980.tb00737.x>

Roa Bastos, F., 'Sociogenèse d'une catégorie politique: l'introduction de "partis politiques au niveau européen» dans le droit communautaire' [Sociogenesis of a political category: the introduction of "political parties at the European level" in community law], Cultures \& Conflits, 85/86 (2012), pp. 99-122, <https:// doi.org/10.4000/conflits.18345>

Scarrow, S., 'Parties and the expansion of direct democracy: who benefits?', Party Politics, 5/3 (1999), pp. 341-62, <https://doi.org/ $10.1177 / 1354068899005003005>$

—, 'Carrots and Sticks, Chickens and Eggs: Understanding Variations in Party Finance Regulatory Regimes', Paper presented at the IPSA/ECPR conference 'What Ever Happened to North-South', Sao Paolo, 16-19 February 2011

-, Beyond Party Members: Changing Approaches to Partisan Mobilization (Oxford: Oxford University Press, 2015)

Schattschneider, E. E., Party Government: American Government in Action (New Brunswick/London: Transaction Publishers, 1942 [2004]) 
Schmitt, H., Hobolt, S. and Popa, S., 'Does personalisation increase turnout? Spitzenkandidaten in the 2014 European Parliament elections', European Union Politics, 16/3 (2014), pp. 347-68, <https://doi.org/ $10.1177 / 1465116515584626>$

Tallberg, J. and Johansson, K. M., 'Party politics in the European Council', Journal of European Public Policy, 15/8 (2008), pp. 1222-42, <https://doi.org/ $10.1080 / 13501760802407755>$

—, 'Party politics in the European Council' in B. Lindberg, A. Rasmussen and A. Warntjen (eds), The Role of Political Parties in the European Union (Oxon: Routledge, 2010)

Usherwood, S., 'Proximate factors in the mobilization of anti-EU groups in France and the UK: the European Union as first order politics', Journal of European Integration, 29/1 (2007), pp. 3-21, <https://doi.org/ $10.1080 / 07036330601144177>$

Usherwood, S. and Startin, N., 'Euroscepticism as a persistent phenomenon', Journal of Common Market Studies, 51/1 (2013), pp. 1-16, <https://doi.org/10.1111/j. 1468-5965.2012.02297.x>

Vasilopoulou, S., 'Continuity and change in the study of Euroscepticism: Plus ça change?', Journal of Common Market Studies, 51/1 (2013), pp. 153-68, <https:// doi.org/10.1111/j.1468-5965.2012.02306.x>

Webb, P., Poletti, M. and Bale, T., 'So who really does the donkey work in "multispeed membership parties"? Comparing the election campaign activity of party members and party supporters', Electoral Studies, 46 (2017), pp. 64-74, $<$ https://doi.org/10.1016/j.electstud.2017.02.002>

Wolfs, W., 'EU party funding: a pro-European instrument to support Euroscepticism?', Paper presented at the Organisation for Economic Cooperation and Development Global Anti-Corruption and Integrity Forum, 3031 March 2017, Paris, <https://www.oecd.org/cleangovbiz/Integrity-

Forum-2017-Wolfs-EU-Party-Funding.pdf>, accessed 19 November 2018

Wolfs, W. and Smulders, J., 'Party financing at the supra-national level: the example of Europe', in J. Mendilow and E. Phéllipeau (eds), Handbook of Political Party Funding (London: Edward Elgar, 2018)

\section{Treaties}

Treaty on European Union [Maastricht Treaty], signed 7 February 1992, Official Journal of the European Communities, No. C191/1, 29 July 1992, <https://eurlex.europa.eu/legal-content/EN/TXT/?qid=1540802419323\&uri=CELEX: $11992 \mathrm{M} / \mathrm{TXT}>$, accessed 29 October 2018 
Treaty of Lisbon amending the Treaty on European Union and the Treaty establishing the European Community [Lisbon Treaty], signed 13 December 2007, Official Journal of the European Union, 50 (C306), 17 December 2007, <https://eur-lex.europa.eu/legal-content/EN/ALL/?uri=OJ:C:2007:306:TOC>, accessed 29 October 2018

Consolidated version of the Treaty on the Functioning of the European Union, Official Journal of the European Union, C202/1, 7 June 2016, <https://eurlex.europa.eu/legal-content/EN/TXT/?uri=CELEX:12016E/TXT>, accessed 29 October 2018

\section{Global Party International statutes and founding documents}

\section{Christian/Centrist Democrat International}

Centrist Democrat International (CDI), 'CDI Basic Plan' (Brussels: CDI, 1995)

\section{Global Greens}

Global Greens, 'Charter of the Global Greens', adopted at the 1st Global Greens Conference, Canberra, Australia, 2001, <https://www.globalgreens.org/ globalcharter>, accessed 29 October 2018

\section{International Democrat Union}

International Democrat Union (IDU), 'The Founding Meeting of the Union and Declaration of Principles', London, 24 June 1983, <https://www.idu.org/about/ history/>, accessed 29 October 2018

\section{Liberal International}

Liberal International, 'Oxford Manifesto', 1947, <https://liberal-international.org/ who-we-are/our-mission/landmark-documents/political-manifestos/oxfordmanifesto-1947/>, accessed 29 October 2018

—, 'The Liberal Agenda for the 21st century' [Oxford Manifesto 1997], adopted by the 48th Congress of Liberal International, 27-30 November 1997, <https:// liberal-international.org/who-we-are/our-mission/landmark-documents/ political-manifestos/oxford-manifesto-1997>, accessed 29 October 2018

—, 'Constitution', as amended and adopted by the 59th Congress, April 2014, $<$ https://liberal-international.org/who-we-are/our-mission/landmarkdocuments/governing-constitution/>, accessed 29 October 2018

—, 'Liberal Manifesto 2017' [Andorra Liberal Manifesto], adopted by the 61st Congress of Liberal International, 18-21 May 2017, <https://liberalinternational.org/who-we-are/our-mission/landmark-documents/politicalmanifestos/liberal-manifesto-2017/>, accessed 29 October 2018 
Progressive Alliance

Progressive Alliance, 'Progressive Alliance for Freedom, Justice and

Solidarity' [Guiding Principles], [n.d.], <http://progressive-alliance.info/ network/guiding-principles/>, accessed 29 October 2018

\section{Socialist International}

Socialist International, 'Aims and Tasks of Democratic Socialism' [Frankfurt Declaration], Declaration of the Socialist International adopted at its First Congress, 30 June-3 July 1951, <http://www.socialistinternational.org/ viewArticle.cfm?ArticleID=39>, accessed 29 October 2018

—, 'Declaration of Principles' [Stockholm Declaration], adopted by the XVIII Congress June 1989, <http://www.socialistinternational.org/viewArticle.cfm? ArticleID=31>, accessed 29 October 2018

\section{Europarty statutes and founding documents}

Alliance of Liberals and Democrats for Europe (ALDE), 'Statutes of the Alliance of Liberals and Democrats for Europe Party, European political party', adopted by the ALDE Party Congress, 1-3 December 2016, Warsaw, <https:// www.aldeparty.eu/sites/alde/files/ alde_statutes_european_party2016_adopted.pdf>, accessed 29 October 2018

European Green Party (EGP), 'Statutes of the European Green Party, European Political Party (PPEU)', adopted at the EGP Council, 12 November 2011, Paris, <https://europeangreens.eu/sites/europeangreens.eu/files/ EGP\%20Statutes\%20as\%20adopted\%20in\%20Karlstad\%20Council.pdf>, accessed 29 October 2018

European People's Party (EPP), 'Statutes of the European People's Party', approved by the EPP Congress, 29 March 2017, Malta, <https://www.epp.eu/files/ uploads/2015/09/EN-STATUTES-version-9-Mai-2017.pdf>, accessed 29 October 2018

Party of European Socialists (PES), 'Statutes of the Socialist International', adopted by the 10th PES Congress, 12 June 2015, <http:// www.socialistinternational.org/viewArticle.cfm?ArticleID=27>, accessed 29 November 2018 


\section{About the authors}

Alex Andrione-Moylan is a research assistant in the Social Sciences faculty of KU Leuven.

Nathalie Brack is an assistant professor at the Political Science Department of the Université Libre de Bruxelles.

Isabelle de Coninck is a research fellow of the Flemish Research Foundation Flanders at the KU Leuven Public Governance Institute.

Stephen Day is a professor of Comparative Politics and EU Studies in the Faculty of Economics at the University of Oita.

Wojciech Gagatek is an assistant professor in the Institute of Political Sciences, Faculty of Political Science and International Studies at the University of Warsaw.

Emilie van Haute is a lecturer and the deputy director or the Centre d'étude de la vie politique at the Université Libre de Bruxelles.

Steven van Hecke is an associate professor of Comparative and EU Politics at the KU Leuven Public Governance Institute. His research focuses on transnational political parties, EU institutions and European integration history, topics about which he has published in various journals and edited volumes. He also has an interest in the role of Belgium within the EU and co-edited Readjusting the Council Presidency: Belgian Leadership with the EU (2011).

Isabelle Hertner is a lecturer in the Politics of Britain in Europe at King's College London.

Karl Magnus Johansson is a professor of Political Science at Södertörn University in Stockholm.

Teona Lavrelashvili is a PhD researcher in the Social Sciences faculty at KU Leuven. 
Gilles Pittoors is a research assistant in the Ghent Association for the Study of Parties and Representation, within the Political and Social Sciences Faculty at Ghent University.

Wouter Wolfs is a research fellow for the Flemish Research Foundation Flanders at the KU Leuven Public Governance Institute. 


\section{About International IDEA}

The International Institute for Democracy and Electoral Assistance (International IDEA) is an intergovernmental organization with the mission to advance democracy worldwide, as a universal human aspiration and enabler of sustainable development. We do this by supporting the building, strengthening and safeguarding of democratic political institutions and processes at all levels. Our vision is a world in which democratic processes, actors and institutions are inclusive and accountable and deliver sustainable development to all.

\section{What do we do?}

In our work we focus on three main impact areas: electoral processes; constitutionbuilding processes; and political participation and representation. The themes of gender and inclusion, conflict sensitivity and sustainable development are mainstreamed across all our areas of work.

International IDEA provides analyses of global and regional democratic trends; produces comparative knowledge on good international democratic practices; offers technical assistance and capacity-building on democratic reform to actors engaged in democratic processes; and convenes dialogue on issues relevant to the public debate on democracy and democracy building.

\section{Where do we work?}

Our headquarters is located in Stockholm, and we have regional and country offices in Africa, the Asia-Pacific, Europe, and Latin America and the Caribbean. International IDEA is a Permanent Observer to the United Nations and is accredited to European Union institutions.

<http://idea.int> 
Democracy involves popular control over decision-making, and political equality among those exercising that control. In parliamentary democracies, day-to-day control is delegated to elected politicians, who organize themselves in political parties. Globally, political parties have become an important interface between government and the people.

Since their establishment, European political parties have enhanced their role(s) within the polity of the European Union. Within the context of multiple challenges to democracy worldwide, and in view of the 2019 European Parliament elections, European political parties are increasingly called upon to represent EU citizens in their work, and ensure an effective connection with people.

This Discussion Paper takes a comprehensive approach to understanding the role(s) of European political parties within the polity of the EU. It focuses on how European political parties can (re)connect with EU citizens, and emphasizes the regulatory framework in which European political parties operate. It also provides insights into European political parties' linkage with national political parties, and outreach in relation to EU political actors and citizens. It includes a set of recommendations to advance the broadening, deepening and diversification of avenues and tools for European political parties to connect with citizens. 